\title{
Bangladesh: Selected Issues
}

This Selected Issues paper for Bangladesh was prepared by a staff team of the International Monetary Fund as background documentation for the periodic consultation with the member country. It is based on the information available at the time it was completed on June 14, 2005. The views expressed in this document are those of the staff team and do not necessarily reflect the views of the government of Bangladesh or the Executive Board of the IMF.

The policy of publication of staff reports and other documents by the IMF allows for the deletion of market-sensitive information.

To assist the IMF in evaluating the publication policy, reader comments are invited and may be sent by e-mail to publicationpolicy@imf.org.

Copies of this report are available to the public from

International Monetary Fund • Publication Services $70019^{\text {th }}$ Street, N.W. $\bullet$ Washington, D.C. 20431

Telephone: (202) 623-7430 • Telefax: (202) 623-7201

E-mail: publications@imf.org •Internet: http://www.imf.org

Price: $\$ 15.00$ a copy

\section{International Monetary Fund Washington, D.C.}





\section{INTERNATIONAL MONETARY FUND}

\section{BANGLADESH \\ Selected Issues \\ Prepared by Olin Liu, Peter Berezin, Jonathan Dunn (all APD), Bernardin Akitoby (FAD), and Luc Moers (PDR) \\ Approved by the Asia and Pacific Department}

June 14, 2005

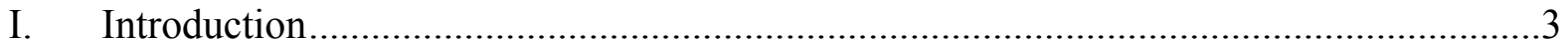

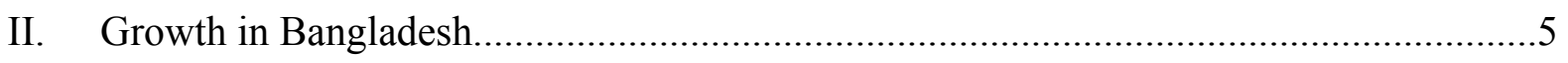

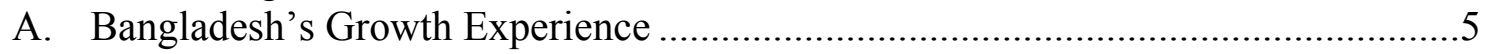

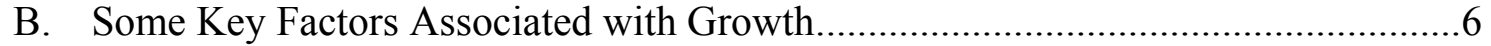

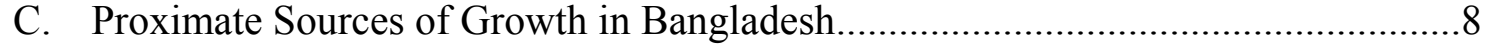

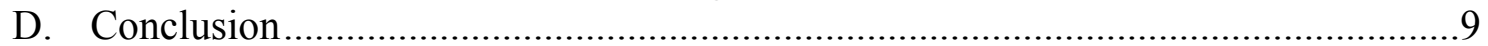

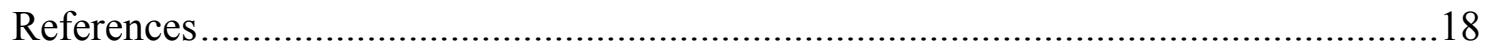

Figures

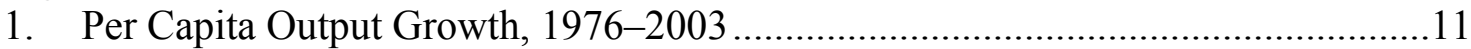

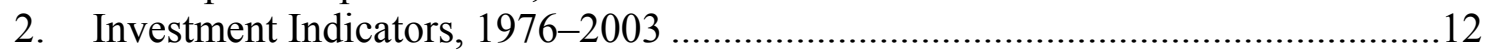

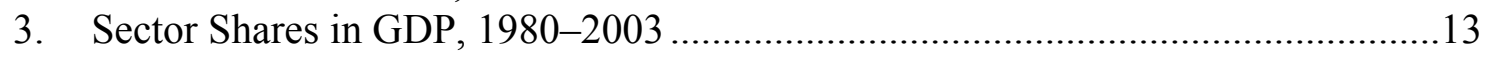

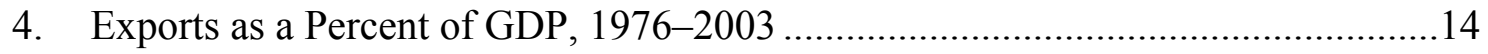

\section{Tables}

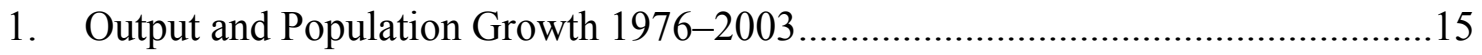

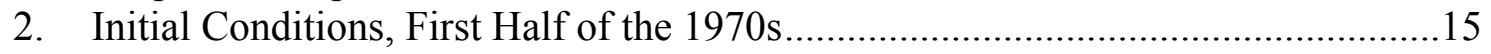

3. Governance Indicators for Bangladesh, 2004 ...................................................... 16

4. Average GDP Growth and Average Sector Shares in GDP, FY 1994-FY2004 ....16

5. Sector Contributions to Growth Acceleration, FY1994-FY2004 ........................17

III. The RMG Sector and External Competitiveness in the Post-MFA World...................19

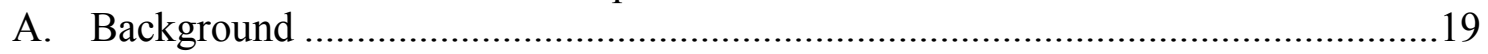

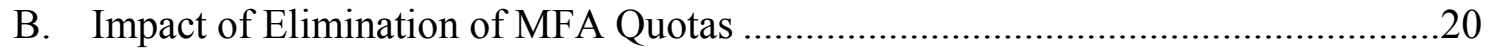

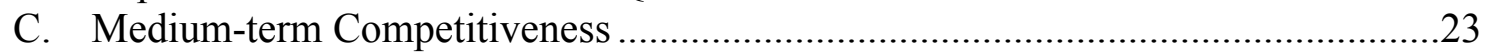

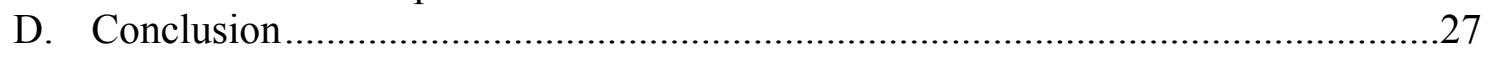

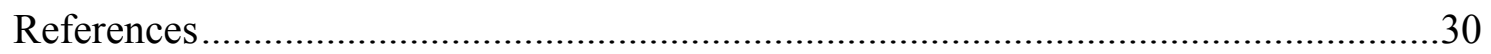


Tables

1. Infrastructure Indicators: Cross-Country Comparisons ....................................28

2. Cost of Doing Business: Bangladesh vs. Comparator Countries ............................28

3. Labor and Productivity Comparisons ................................................................29

4. Rankings of Average Tariffs in South Asia in Relation to Average Tariffs in Other Developing Countries...........................................................................29

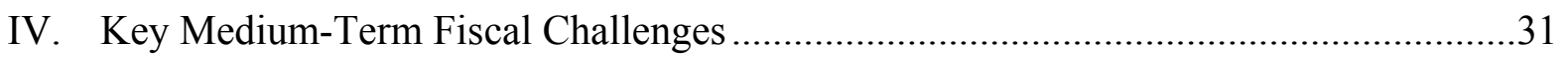

A. Key Challenges in Tax Administration and Policy ........................................... 31

B. Key Challenges in Expenditure Management and Policy ....................................36

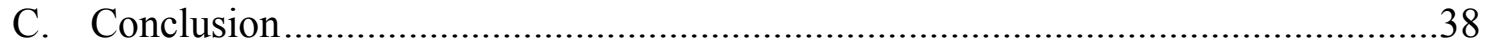

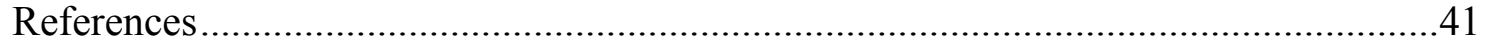

Table

1. Fiscal Reform Priorities.......................................................................... 40

V. Banking Reform in Bangladesh-A South Asian Perspective ....................................42

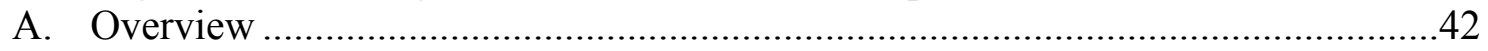

B. Recent Areas of Reform ............................................................................. 44

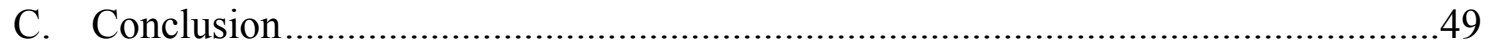

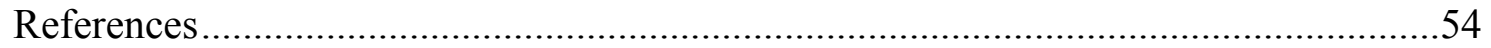

Figures

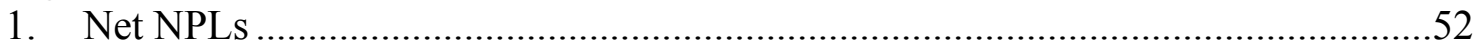

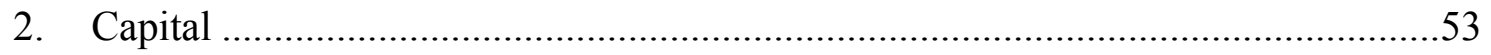




\section{INTRODUCTION}

1. Bangladesh has maintained a stable macroeconomic climate and achieved steady economic growth and poverty reduction in recent years. Despite a difficult political environment, the authorities have continued with the structural reform agenda in tax administration and nationalized commercial banks (NCBs), together with measures to liberalize the investment regime and reform state-owned enterprises (SOEs). Nevertheless, the economy remains among the poorest in Asia. Ambitious and sustainable policy reforms are needed to accelerate growth and fulfill the Millennium Development Goals (MDGs).

\section{A roadmap to further poverty reduction has also been cast in the authorities'}

Poverty Reduction Strategy Paper (PRSP), which is expected to be published by end-2005. The priorities will be centered on prioritizing near-term policies in key sectors and antipoverty programs, incorporating the costing of the proposed sectoral projects into the medium-term budgetary framework, improving the monitoring and evaluation mechanism of social development, and initiating a poverty and social impact assessment of the reform strategy. Risks to the implementation of reforms are significant, however. Growth in Bangladesh has been adversely affected by inadequate investment in physical infrastructure and human capital, a fractious political environment, and poor governance in the institutional machinery. Chapter II reviews Bangladesh's recent growth experience, while Chapters III-V address the key issues that lie at the heart of Bangladesh's economic revival.

\section{Faster and lasting growth is key to poverty reduction in Bangladesh.}

Bangladesh's low initial level of income, continued macroeconomic stability, and recent financial sector and other structural reforms have all contributed to sustained increases in per capita income. However, Chapter II identifies several key impediments to growth, namely: poor governance (as manifested by widespread incidences of corruption); restrictive trade and regulatory regimes; and inadequate investment in human capital and physical infrastructure. The growth of the ready-made-garment (RMG) sector over the past decade was fueled in part by the comparative advantage that Bangladesh enjoys from its abundance of low-cost labor. As long as measures are taken to boost labor productivity by strengthening education, improving the investment climate, reducing corruption, and upgrading infrastructure, Bangladesh's growth prospects will continue to be favorable. Moreover, such reforms will help diversify the economy towards other export-oriented activities that require an abundance of low-cost labor.

4. Bangladesh has been very reliant on the RMG sector for export earnings. This industry has been the primary engine of growth in the manufacturing sector and a critical source of employment, especially for women. In the near term, however, Bangladesh will be confronted by the impact of the phase-out of the Multifiber Trade Arrangement (MFA). As discussed in Chapter III, the potential risks are substantial considering that more than threequarters of exports stem from the RMG sector. While the early indications suggest that orders for RMG exports have held up well, Bangladesh can not afford to be complacent. The paper outlines key steps that need to be taken to boost external competitiveness. This entails reducing tariffs and duties to decrease the cost of imported capital machinery and textiles, 
improving port facilities, reducing regulations and customs delays, and maintaining a flexible exchange rate.

5. Strengthening tax administration is vital to maintaining macroeconomic stability and generating sufficient resources to finance pro-poor development spending. However, structural fiscal problems have kept revenue and public expenditure below the path needed for faster reduction in poverty. Chapter IV makes the case that the medium-term fiscal strategy should be centered on boosting the revenue performance of the National Board of Revenue (NBR) by reorganizing it along functional lines, adopting a system of selfassessment, establishing a risk-based auditing system, and introducing a unique taxpayer identification number (TIN). In tax policy, the medium-term priorities should be to widen the VAT and income tax bases and further reduce and rationalize import tariffs and supplemental duties, while identifying alternative revenue sources to protect revenue.

6. Sound expenditure management is key to ensuring that limited government resources are channeled to areas that will contribute the most to sustainable growth. To this end, Chapter IV also discusses several ways to boost the efficacy of the Annual Development Program (ADP), including improving project selection and monitoring, and strengthening procurement guidelines. Additionally, to ensure that the public sector wage bill does not crowd out development expenditures, the paper outlines the broad principles of reform of the civil service.

\section{An efficient banking system is critical to boosting savings and productive} investment. Chapter $\mathrm{V}$ examines bank reform in a regional context. All four countries surveyed - Bangladesh, India, Pakistan, and Sri Lanka - have made significant strides to modernize their banking systems. Bangladesh, in particular, has made significant progress in liberalizing the banking sector, improving prudential controls and supervision, and paving the way towards divesting its NCBs. These reforms have resulted in lower levels of nonperforming loans and improved profitability and capital adequacy.

8. In sum, Bangladesh continues to face significant medium-term challenges, particularly in implementation of the structural reform agenda in a difficult political environment. The authorities' continued strong commitment to the overall reform process to support fast growth and poverty reduction is reassuring. Nevertheless, much work remains to be done to achieve the MDGs, including maintaining macroeconomic stability, advancing structural reforms, developing a more comprehensive approach to tackle governance issues, and strengthening law and order. 


\section{GROWTH IN BANGLADESH ${ }^{1}$}

9. This chapter examines Bangladesh's economic growth in comparison to that of other low-income countries (LICs) and some countries in Asia, and looks at the country's relative progress toward some of the key MDGs in view of these growth trends. Section A describes Bangladesh's recent growth experience from 1976-2003 and compares its growth performance with that of other countries. Section B provides a brief comparative analysis with respect to some key factors that have been positively associated with economic growth. Section $\mathrm{C}$ draws on the existing growth literature on Bangladesh to provide a descriptive analysis of the sources of growth in the country and also looks at the structure of GDP and the ratio of exports to GDP across countries in the region. Section D assesses Bangladesh's progress on some key MDGs and concludes.

\section{A. Bangladesh's Growth Experience}

10. Bangladesh's growth performance has improved steadily since the mid-1970s. Real GDP growth accelerated from an average of 3.8 percent in 1976-1985 to 4.8 percent in 1996-2003 (Table 1). The improvement in average per capita GDP growth over the same period was even more impressive as a result of the sharp decline in the population growth rate beginning in the early 1990s.

11. This strong recent per capita growth performance, aided by the beneficial impact of NGO social programs and broad-based micro credit programs, has been propoor. The incidence of poverty in Bangladesh, as measured by the proportion of the population falling below the national poverty line, fell by about 1 percentage point per year during the 1990s, from 59 percent in 1991 to just under 50 percent in 2000.

12. Notwithstanding the substantial improvement in its growth performance over the past 30 years, Bangladesh has continued to lag behind LICs as a group and other Asian economies for most of this period. Bangladesh's growth performance was less strong than the average for groupings of low income countries and countries in Asia throughout the period. Beginning in the late 1990s, however, Bangladesh's growth performance began to outstrip that of some of its neighbors, and also that of countries that were severely affected by the Asian crisis (Figure 1). ${ }^{2}$

\footnotetext{
${ }^{1}$ Prepared by Jonathan Dunn (APD).

${ }^{2}$ Unless otherwise noted, for comparability and consistency across countries, all data used in this chapter are drawn from the World Bank's World Development Indicators (WDI) database. GDP in all cross-country/region figures is measured in constant 2000 PPP international dollars.
} 


\section{B. Some Key Factors Associated with Growth}

13. This section provides a simple comparative analysis of Bangladesh, LICs as a group, and other countries in Asia with respect to a number of indicators that have been associated with growth prospects. ${ }^{3}$ The factors assessed in this section are initial conditions, macroeconomic policy stability, financial market depth and efficiency, physical infrastructure and human capital development, external conditions - as measured by the terms of trade and foreign assistance for development, trade openness, and the quality of institutions or governance.

14. Bangladesh's initial economic conditions were below average for LICs in the first half of the 1970s. Per capita GDP in PPP dollars was 94 percent of the LIC average (Table 2) and also lagged behind the average for South Asian countries. Both life expectancy and the literacy rate, which can be taken as indicators of past investment in human capital, were below the average for countries of similar income levels or in the same region. Traditional growth theory postulates that countries with low initial conditions should grow relatively fast, so growth in Bangladesh would have been expected to be stronger due to its relatively weak starting point.

15. Macroeconomic policy indicators in Bangladesh have been better than in neighboring countries. Inflation has been well below that in other Asian countries over the period 1987-2003 and price volatility has been somewhat less than in other countries in the region for much of the same period. Moreover, inflation in Bangladesh has declined at a steady pace, falling from an average of 6 percent in 1987-95 to 4 percent in 1996-2003. Bangladesh's central government debt as a percent of GDP is moderate compared to other countries, with most external debt (two-thirds of the total) contracted on concessional terms. Growth has been shown by numerous studies to be strongly and positively correlated with a stable macroeconomic environment.

16. Bangladesh is characterized by shallow and inefficient financial markets. Broad money as a percent of GDP has been consistently lower than the LIC average and than in other South Asian countries throughout the period 1976-2003. Average interest rate spreads since 1990 - measured as the difference between prime lending rates and commercial bank deposit rates - in Bangladesh have also been greater than in other countries. These facts indicate that financial markets in Bangladesh have been relatively inefficient at financial intermediation, which has probably undermined growth performance. However, over the past five years interest rate spreads have declined as the economy has become more monetized, reflecting the positive outcomes of reforms in the banking system.

17. Physical and human capital development in Bangladesh lag behind most of the sample countries and the averages for Asia and for countries of similar income levels.

\footnotetext{
${ }^{3}$ The countries compared differ across the factors being assessed due to data availability constraints.
} 
Physical infrastructure development, as proxied by the percent of roads that are paved and by the number of mobile and fixed line telephone subscribers per 1,000 people, is significantly lower in Bangladesh than in comparator countries. The pupil-teacher ratio, a reasonable indicator of opportunities for effective human capital development, remains very high in Bangladesh. Adult literacy rates, which were low initially, have improved, but remain well below those in other LICs and the average for South Asia, indicating insufficient investment in human capital. Gross domestic investment and gross foreign direct investment have also lagged well behind that in the comparator countries (Figure 2).

18. External conditions have been mixed. Bangladesh's terms of trade were relatively favorable, but quite unstable, throughout the 1980s and 1990s, reflecting volatile export prices. Bangladesh has benefited from very substantial foreign remittances, especially in the past decade, with remittances reaching more than 6 percent of GDP in 2004. The country also received large amounts of foreign assistance over the past 30 years, though this has fallen off since the mid-1990s.

19. Bangladesh's economy has been relatively closed over the past several decades. Total trade, taken as a measure of trade openness, has accounted for around 20 to 30 percent of GDP over this period. This is well below the average for LICs and countries in East Asia, although somewhat better than the South Asian average. Trade taxes collected in Bangladesh have imposed a relatively heavy burden on the economy and reflect Bangladesh's relatively closed trade regime. Finally, as noted above, gross foreign direct investment, which can be taken as a reflection of economic openness, has always been low in Bangladesh. ${ }^{4}$

\section{Empirical studies support a strong positive relationship between better} governance and good institutions, and high per capita incomes and better growth. ${ }^{5}$ A set of well-known and recently updated indicators developed at the World Bank serve as good proxies for the measurement of how strong and transparent institutions in a country are. ${ }^{6}$ Bangladesh's position in this regard is mixed. The country performs better than the average for countries at its income level in terms of the perceived effectiveness of government (meant to capture bureaucratic competence and the effectiveness of public service delivery) and in voice and accountability (a measure of civil and political rights) (Table 3). On other indicators, however, Bangladesh lags behind the comparator countries, particularly for the measures relating to regulatory quality (incidence of market-unfriendly policies) and control of corruption (exercise of public power for private gain).

\section{Aside from the factors above associated with growth, it is instructive to look at how Bangladesh compares with other countries in terms of the structure of its GDP and}

\footnotetext{
${ }^{4}$ For example, Bangladesh only recently removed restrictions on FDI in the garment sector.

${ }^{5}$ See, for example, Kaufmann and Kraay (2002) and Bosworth and Collins (2003).

${ }^{6}$ Kaufmann, Kraay, and Mastruzzi (2005). This study standardizes the measurement of governance indicators on a scale of -2.5 (worst) to +2.5 (best).
} 
the evolution of exports to GDP in recent years. The shares of agriculture, industry, and services in GDP in Bangladesh have been comparable to those in other countries in South Asia over the past 20 years and these shares have been quite static (Figure 3 ). This differs substantially when compared to the average sector shares for GDP in countries in East Asia and the Pacific, with these countries characterized by decreasing, and much smaller, shares of agriculture and increasing shares of industry. At the same time, Bangladesh's ratio of exports to GDP is low when compared to most other countries in South Asia and to countries in East Asia and the Pacific (Figure 4). This suggests that export-led industrialization, which has contributed substantially to growth in many Asian economies, is an important consideration for Bangladesh, and Bangladesh's success in recent years with the development of the exportoriented ready made garments (RMG) sector reinforces this notion.

\section{Proximate Sources of Growth in Bangladesh}

22. This section examines sector contributions to growth in Bangladesh over the past decade and refers to some of the existing evidence on the sources of growth in Bangladesh based upon a growth accounting framework.

\section{Recent sector contributions to growth}

\section{Average annual GDP growth in Bangladesh increased from 4.8 to 5.3 percent} over the past decade (Table 4). This higher growth has been accompanied by a slight shift between the shares of agriculture and industry in GDP; the share of services has remained roughly constant.

24. Different sectors made widely varying contributions to the acceleration in growth over the past decade. Table 5 shows the incremental increase in value added in the economy in the most recent five years compared to the previous five years, and the contribution of each sector. While the sector shares in GDP have remained relatively stable, the contributions to growth have been mainly from services and industry, in particular from manufacturing, construction, retail trade and transportation. Crop production also contributed very significantly to the growth trend, although the overall contribution of agriculture was small due to the collapse in value added from fishing.

25. Some of the key factors associated with growth in Bangladesh-discussed above in Section B - can be linked to recent sector growth performance. Sound macroeconomic policies, complemented by recent financial sector reforms, have permitted the financial sector to grow and become more efficient. The corresponding expansion in private banking has helped to finance investment in the RMG sector, as well as in associated (and other) construction and distribution activities, and thereby has helped to fuel growth in these sectors. Similarly, trade reform has helped the country to generate enough export earnings to finance the import of capital machinery and this has helped to drive industrial growth. Recent efforts to improve the energy infrastructure and energy service delivery have helped boost productivity and have thereby contributed to growth.

26. Within manufacturing, the RMG sector is estimated to have been the largest single contributor to growth over the past decade, and is now contributing between 20 
and 25 percent of total value added in large and medium manufacturing. ${ }^{7}$ The $\mathrm{RMG}$ sector has also come to dominate the export earnings of Bangladesh, rising from 10 percent of total export earnings in 1984 to 75 percent in 2004. Moreover, RMG exports have accounted for almost 83 percent of the growth in the value of exports of the country over this period. Thus, this sector, which has benefited from trade reforms, is providing a very substantial portion of the export earnings needed to finance investment in this and other sectors and boost growth.

\section{Evidence from recent growth studies on Bangladesh}

27. Growth equations estimated in two recent studies provide strong evidence that the factors outlined in Section B are relevant to the growth process in Bangladesh. ${ }^{8}$ Both studies show that investment and educational attainment boost growth and that poorer initial economic conditions, as postulated in the growth literature, are associated with stronger growth in Bangladesh. The comprehensive study of growth and productivity in Bangladesh by Mahajan (2005) shows that growth is negatively related to an indicator on financial market concentration (presumed inefficiency) and is positively related to better institutions/governance, macroeconomic stability, and lower volatility in the terms of trade.

\section{Conclusion}

28. The factors common to the growth literature that are explored in Section B indicate that Bangladesh's growth performance over approximately the past 30 years would have been expected to gain from poor initial conditions and prudent macroeconomic policies. The country has, however, probably been held back for much of this period by its weak financial markets, inadequate development of physical and human capital, relatively closed economy, and governance problems. These results are borne out by recent empirical studies of growth and productivity in Bangladesh. Bangladesh's external conditions have been mixed, with substantial volatility in the terms of trade but also very rapid growth in worker remittances that should have acted to stimulate domestic demand and, either directly or indirectly, domestic savings and investment.

29. Bangladesh has become very reliant on the RMG sector for export earnings and this sector has served as an engine of growth in the manufacturing sector and for the economy. Agriculture, particularly crop production, remains an important contributor to growth and incomes in Bangladesh, especially in rural areas. Because of the concentration of relatively poor manufacturing workers in the RMG sector and the rural poor in agriculture and rural nonfarm activity, continued growth in these sectors is crucial to ensuring further reductions in poverty and meeting Bangladesh's MDG goals.

\footnotetext{
${ }^{7}$ Osmani, Mahmud, Sen, Dagdeviren, and Seth (2003).

${ }^{8}$ Mahajan (2005); Roberts and Fagernäs (2004).
} 
30. Bangladesh derives a substantial comparative advantage from its very low wage base. The country should be able to benefit from this so long as reforms continue to improve infrastructure, reduce corruption, and otherwise improve the investment climate, which should allow for an increase in both domestic and foreign direct investment. This would support economic diversification into other export-oriented activities that require an abundance of low-cost labor (electronics assembly, toys, bicycles, etc.) and that could fuel further growth. This diversification would also benefit the economy by reducing the country's reliance on export earnings from the RMG sector and providing alternative sources of funding for investment and imports of capital machinery.

31. While Bangladesh's growth performance has improved steadily, it nonetheless continued to lag behind the average growth rate for LICs and South Asian countries in recent years, and its poverty rate remains relatively high. At the same time, Bangladesh strongly outperformed LICs and the South Asian average on some key indicators related to attainment of the MDGs, namely primary education completion rates, the ratio of girls to boys enrolled in school, and child and maternal mortality rates. This paradox may be partly explained by the historically strong role of NGOs in Bangladesh in delivering social, education, and health services.

32. The establishment of independent regulatory bodies and the reduction of rentseeking opportunities through structural reforms of the financial, energy, and other sectors are therefore crucial in order to remove constraints on growth. The governance indicators in Table 3 suggest that the delivery by government of public services and the quality of the bureaucracy are relatively strong, while at the same time the government is seen to be heavy handed in the regulatory sphere, and regulatory capacity and rent seeking in the public sector are problematic. This indicates that the government is perceived to be relatively efficient at delivering public services, such as education and health, but there are different perceptions with respect to its other responsibilities. 
Figure 1. Per Capita Output Growth, 1976-2003
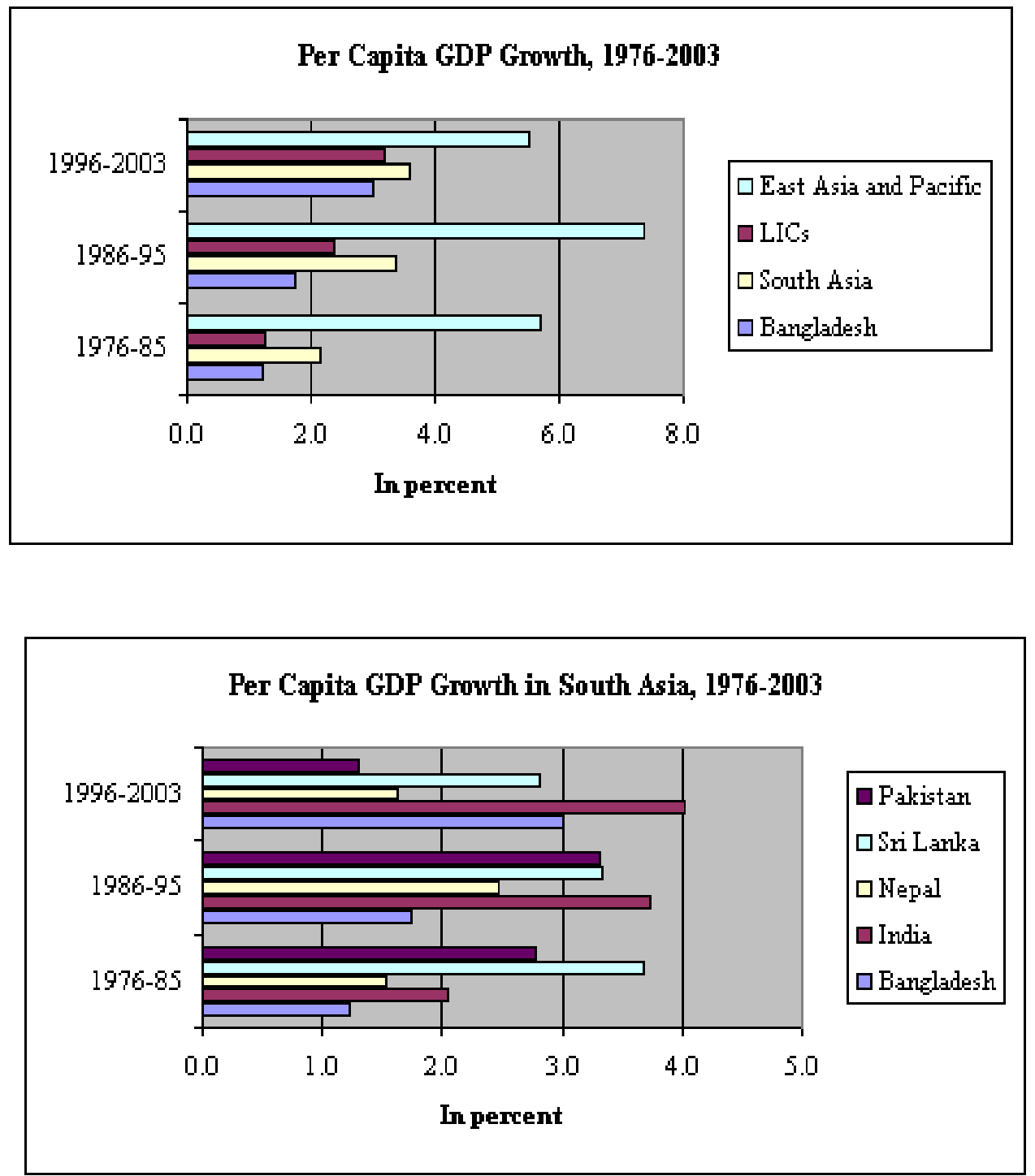

Sources: WDI; and Fund staff calculations. 
Figure 2. Investment Indicators, 1976-2003
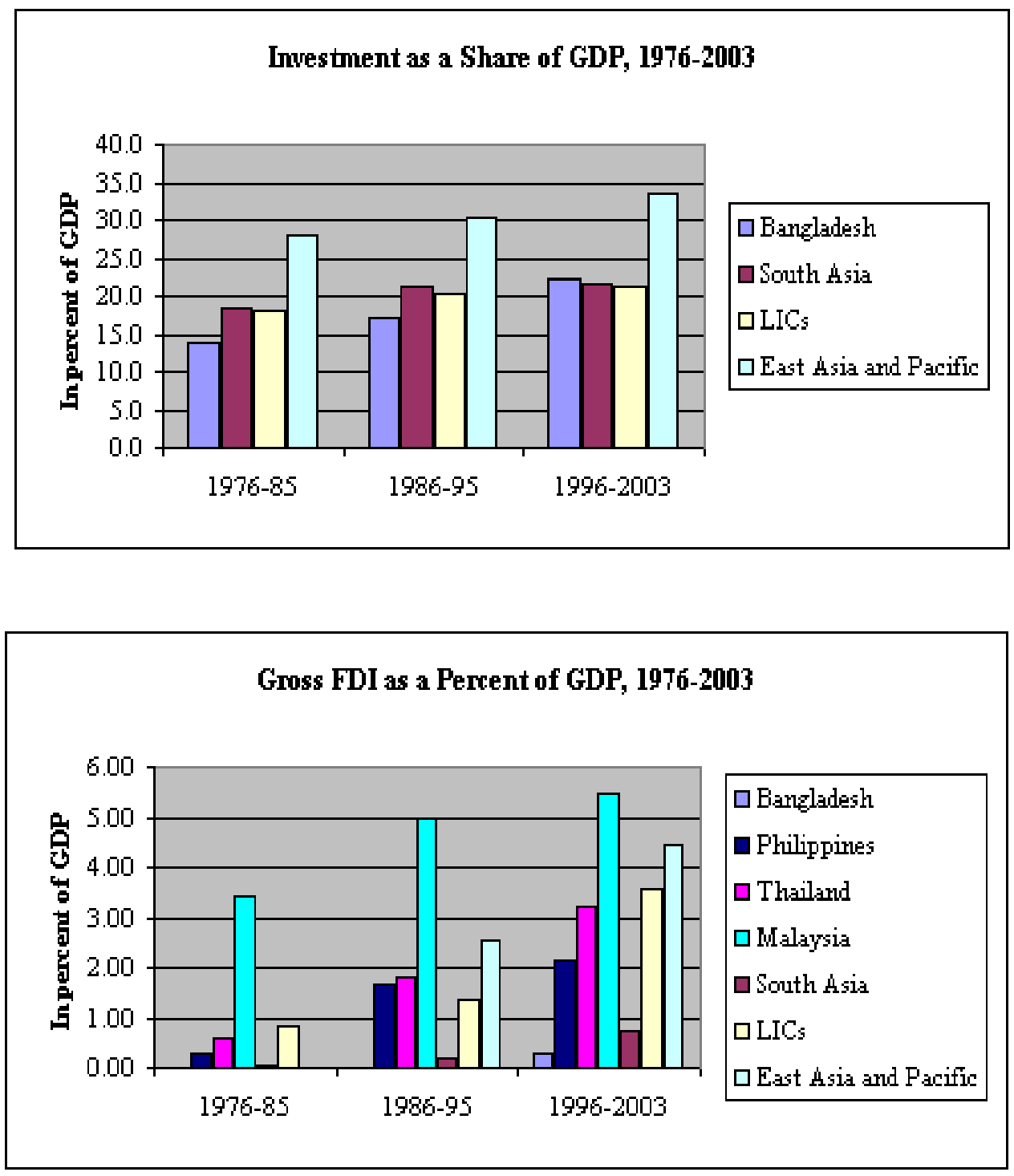

Sources: WDI; and Fund staff calculations. 
Figure 3. Sector Shares in GDP, 1980-2003
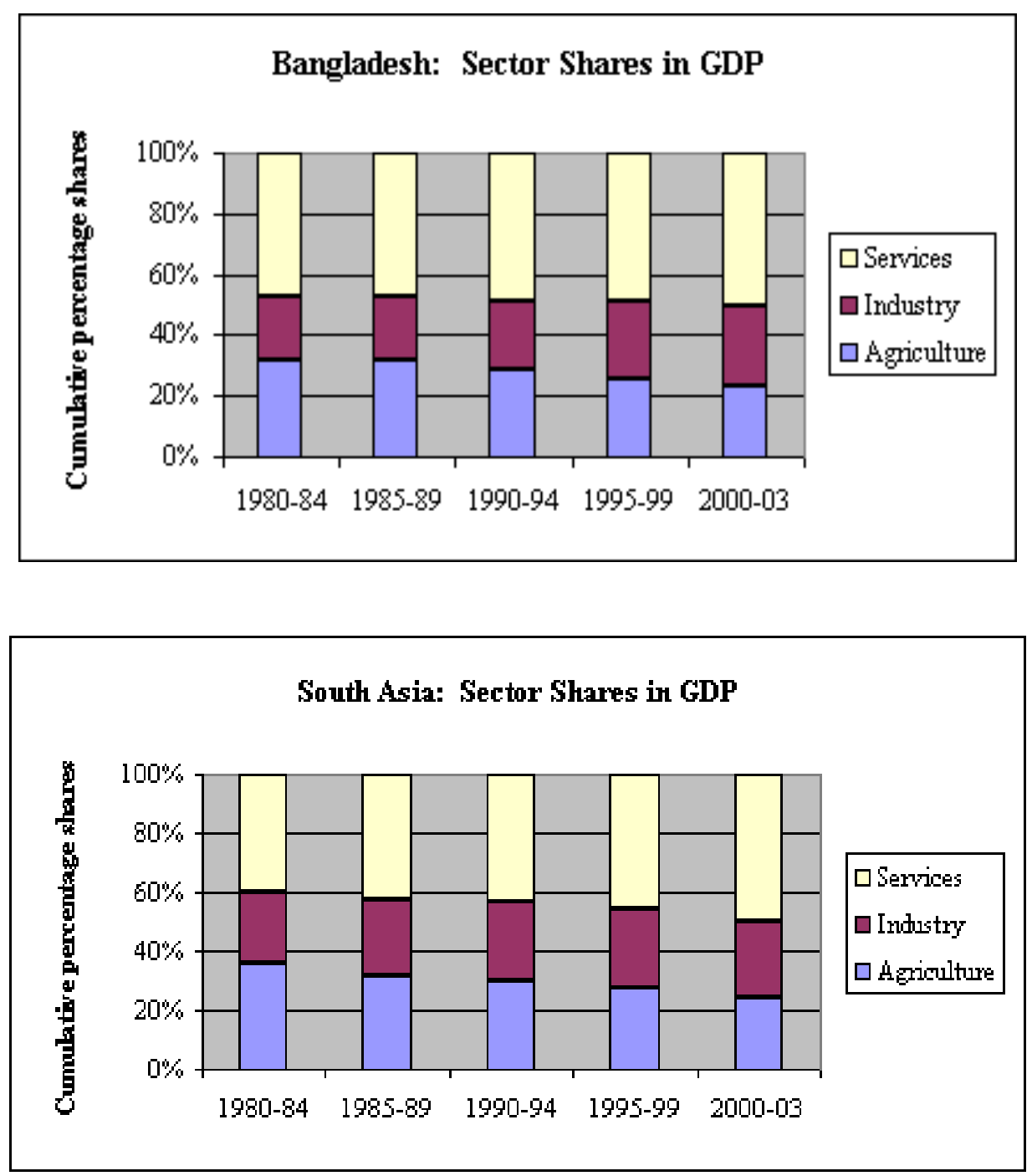

Sources: WDI; and Fund staff calculations. 
Figure 4. Exports as a Percent of GDP, 1976-2003
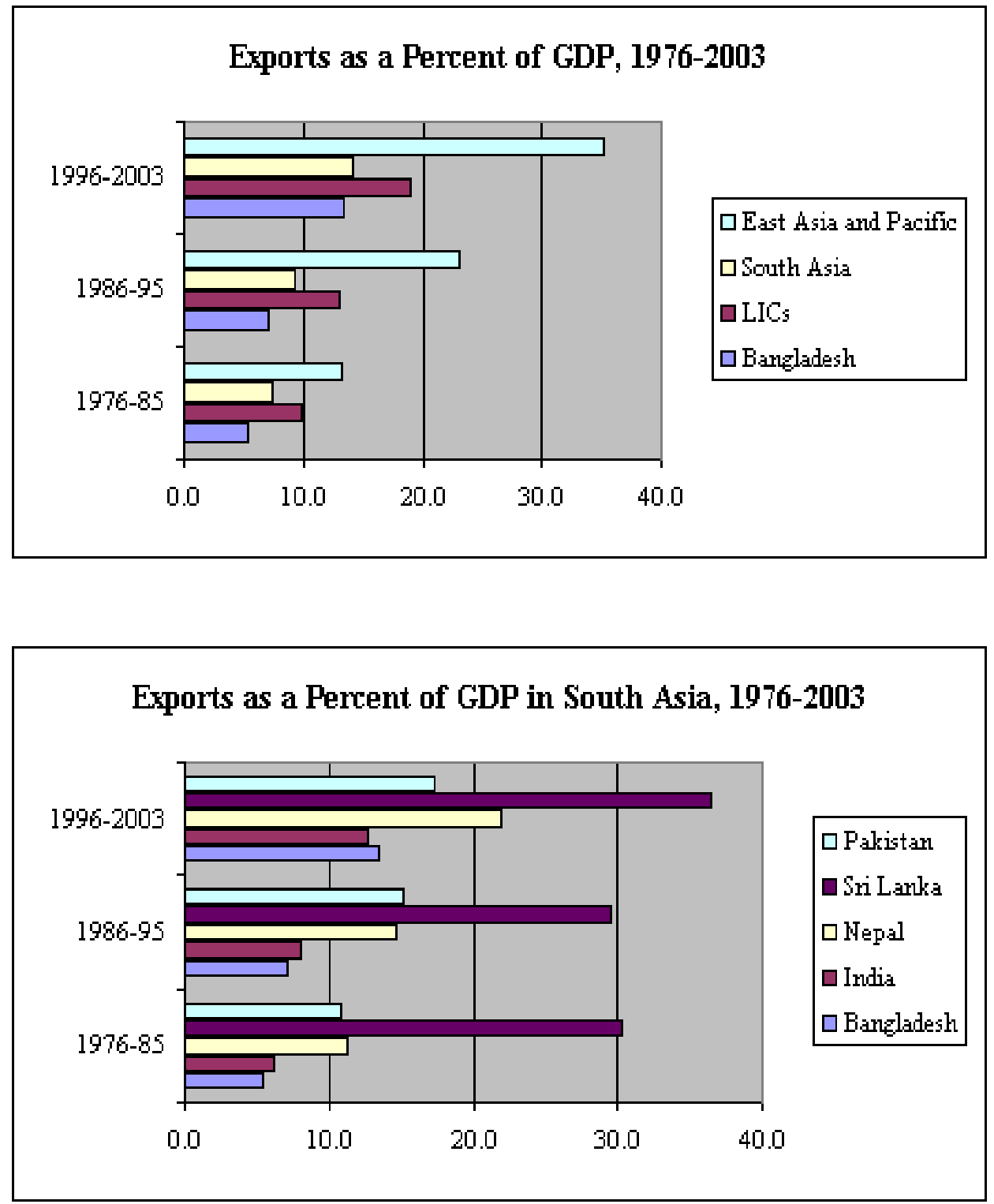

Sources: WDI; and Fund staff calculations. 
Table 1. Bangladesh: Output and Population Growth, 1976-2003

\begin{tabular}{|c|c|c|c|}
\hline & $1976-85$ & $1986-95$ & $1996-2003$ \\
\hline Average GDP growth & 3.8 & 3.9 & 4.8 \\
\hline Average per capita GDP growth & 1.2 & 1.7 & 3.0 \\
\hline \multicolumn{4}{|l|}{ Memorandum item: } \\
\hline Average population growth & 2.5 & 2.1 & 1.7 \\
\hline
\end{tabular}

Sources: WDI; and Fund staff calculations

Table 2. Initial Conditions, First Half of the 1970s

\begin{tabular}{|c|c|c|c|}
\hline & $\begin{array}{r}1975 \\
\text { Per capita GDP } \\
\text { (2000 PPP\$) }\end{array}$ & $\begin{array}{r}1972 \\
\text { Life expectancy } \\
\text { (in years) }\end{array}$ & $\begin{array}{r}1975 \\
\text { Literacy rate } \\
\text { (adult, 15+ } \\
\text { yrs) }\end{array}$ \\
\hline Bangladesh & 986 & 45 & 27 \\
\hline Relative to LIC average (in percent) & 94 & 93 & 71 \\
\hline Relative to South Asia average (in percent) & 96 & 90 & 76 \\
\hline South Asia & 1,022 & 50 & 36 \\
\hline India & 1,139 & 50 & 37 \\
\hline Pakistan & 989 & 51 & 24 \\
\hline Nepal & 801 & 43 & 19 \\
\hline Sri Lanka & 1,443 & 65 & 83 \\
\hline LICs & 1,053 & 48 & 38 \\
\hline Malaysia & 2,998 & 63 & 65 \\
\hline Thailand & 1,899 & 60 & 84 \\
\hline
\end{tabular}

Sources: Bangladesh authorities; and Fund staff calculations. 
Table 3. Governance Indicators for Bangladesh, 2004

\begin{tabular}{lcccc}
\hline & $\begin{array}{c}\text { Percentile } \\
\text { Rank }\end{array}$ & Estimate & $\begin{array}{c}\text { Income } \\
\text { Category } \\
\text { Average, } \\
\text { Percentile }\end{array}$ & $\begin{array}{c}\text { Regional } \\
\text { Average, } \\
\text { Percentile }\end{array}$ \\
\hline Voice and accountability & $(0-100)$ & $(-2.5$ to +2.5$)$ & 27.8 & 25.4 \\
Political stability & 28.6 & -0.69 & 26.7 & 26.4 \\
Government effectiveness & 11.7 & -1.24 & 21.5 & 38.5 \\
Regulatory quality & 26.4 & -0.72 & 25.1 & 30.8 \\
Rule of law & 13.3 & -1.15 & 23.0 & 34.2 \\
Control of corruption & 22.2 & -0.86 & 23.5 & 37.9 \\
\hline
\end{tabular}

Source: Kaufmann, Kraay, and Mastruzzi (2005).

Table 4. Bangladesh: Average GDP Growth and Average Sector Shares in GDP, FY1994-FY2004

FY1994 to FY1999

FY1999 to FY2004

Average GDP growth

Average sector shares in GDP

I. Agriculture, Forestry and Fishing

II. Industry

III. Services
(Percent per annum)

4.8

5.3

(In percent)

25.9

24.8

49.3

26.6

49.1

Sources: Bangladesh authorities; and Fund staff calculations. 
Table 5. Bangladesh: Sector Contributions to Growth Acceleration, FY1994-FY2004 (In billions of taka in 1995/96 prices, unless otherwise indicated)

\begin{tabular}{|c|c|c|}
\hline & $\begin{array}{r}\text { Incremental Value Added } \\
\text { During FY1999/2004 } \\
\text { Compared to } \\
\text { During FY1994/1999 }\end{array}$ & $\begin{array}{r}\text { Share in Incremental } \\
\text { Value Added }\end{array}$ \\
\hline Gross Domestic Product & 156.3 & $100.0 \%$ \\
\hline I. Agriculture, Forestry and Fishing & 10.1 & $6.4 \%$ \\
\hline Agriculture and forestry & 31.8 & $20.3 \%$ \\
\hline Crops and horticulture & 23.8 & $15.2 \%$ \\
\hline Animal farming & 5.1 & $3.3 \%$ \\
\hline Forest and related services & 2.9 & $1.8 \%$ \\
\hline Fishing & -21.7 & $-13.9 \%$ \\
\hline II. Industry & 53.3 & $34.1 \%$ \\
\hline Mining and quarrying & 3.7 & $2.4 \%$ \\
\hline Manufacturing & 21.6 & $13.8 \%$ \\
\hline Large- and medium-scale & 9.8 & $6.3 \%$ \\
\hline Small-scale & 11.8 & $7.6 \%$ \\
\hline Electricity, gas, and water & 6.8 & $4.4 \%$ \\
\hline Construction & 21.1 & $13.5 \%$ \\
\hline III. Services & 93.0 & $59.5 \%$ \\
\hline Wholesale and retail trade & 29.3 & $18.7 \%$ \\
\hline Hotels and restaurants & 1.9 & $1.2 \%$ \\
\hline Transport, storage, and communication & 26.7 & $17.1 \%$ \\
\hline Financial intermediation & 3.8 & $2.5 \%$ \\
\hline Real estate activities & 5.2 & $3.3 \%$ \\
\hline Public administration and defense & 5.0 & $3.2 \%$ \\
\hline Education & 8.2 & $5.2 \%$ \\
\hline Health and social works & 5.2 & $3.3 \%$ \\
\hline Community, social, and personal services & 7.7 & $4.9 \%$ \\
\hline
\end{tabular}

Sources: Bangladesh Bureau of Statistics; and Fund staff calculations. 


\section{REFERENCES}

Bosworth, Barry, and Susan M. Collins, 2003, "The Empirics of Growth: An Update," Brookings Institution.

Kaufmann, Daniel, and Aart Kraay, 2002, “Growth Without Governance.” Economia, Volume 3, Number 1.

— 1996-2004,” The World Bank (Washington, D.C.).

Osmani, S. R., Wahiduddin Mahmud, Binayak Sen, Hulya Dagdeviren, and Anuradha Seth, 2003, "The Macroeconomics of Poverty Reduction: The Case Study of Bangladesh," UNDP.

Mahajan, Sandeep, 2005, "Sources of Growth and Productivity in Bangladesh." The World Bank, mimeograph.

Roberts, John, and Sonja Fagernäs, 2004, "Why is Bangladesh Outperforming Kenya? A Comparative Study of Growth and its Causes since the 1960s," ESAU Working Paper No. 5 (London: Overseas Development Institute, London). 


\section{The RMg Sector And EXternal Competitiveness in the Post-MFA World ${ }^{9}$}

33. This chapter assesses Bangladesh's external competitiveness in the context of the RMG sector after the full phase-out of the quotas dating back from the 1974 MFA. On January 1, 2005, the set of bilateral quotas that had governed trade in RMG for over 30 years was eliminated. As these quotas had led to an artificial trade structure, the international RMG market faces a restructuring process.

34. Bangladesh's exports are heavily concentrated in the RMG sector, which has been a main driver of growth and poverty reduction. With more than three-quarters of exports RMG related, the country is vulnerable to the MFA shock, in particular since it is confronted with other problems that affect its competitiveness. These problems are not limited to the RMG sector, but will be exposed more fully there in the post-MFA world. The challenge is therefore to improve competitiveness, both in the RMG sector and economy wide, and diversify exports, thus contributing to increased growth and poverty reduction. Section A describes the RMG sector in Bangladesh. This gives some background for a brief assessment of the impact of the elimination of MFA quotas so far, including specific policy reactions, in Section B. Section $\mathrm{C}$ moves beyond the short-term impact on the RMG sector, to Bangladesh's medium-term competitive position in general, looking at its main determinants. Section D concludes.

\section{A. Background}

35. Bangladesh's RMG sector emerged out of the MFA of 1974. The MFA subjected RMG-exporting countries to quotas for their exports to major importing markets, primarily to the European Union (EU) and the United States (US). Yet, for Bangladesh, the quotas helped to establish market presence as a kind of shield from major regional competitors, in particular China. About 95 percent of Bangladesh's RMG exports go to the EU (55 percent) and US (40 percent).

\section{The RMG sector has been the main source of export growth and formal}

employment in Bangladesh. RMG exports accounted for almost 83 percent of the growth in the value of Bangladesh's total exports between 1984 and 2004. The share of RMG in total exports thus increased from 10 to 75 percent over the same period, one of the highest shares among major RMG exporting countries. The sector plays a key role in employment and in the provision of income to the poor, directly employing almost 2 million people, or about 40 percent of manufacturing sector employment, 90 percent of whom are women. The abundance of low-wage labor is Bangladesh's main competitive advantage. Indirectly the RMG sector supports about 10 to 15 million people. Over the past 20 years, the number of manufacturing units has grown from 180 to over 3,600, 95 percent of which are locally owned. The typical firm employs 200 to 1,200 workers, with an average of about 550 to 600

\footnotetext{
${ }^{9}$ Prepared by Luc Moers (PDR).
} 
workers. Some 90 percent of the factories are located in and around the capital Dhaka, and the port of Chittagong.

37. The direct contribution of the RMG sector to GDP is estimated at about 5 percent only, due to a high import content. Most of Bangladesh's RMG exports are made from imported textiles. The country has a small textiles industry, but the volume and quality of its output are unable to meet the demands of the RMG sector. This, incidentally, is an important source of conflict between the industry associations of these two sectors, which often frustrates the implementation of good policies, for example abolishing long-standing quantitative restrictions on textiles imports, which was forced through only recently. Bangladesh also imports most of its needs in cotton and other raw materials for the textile industry.

38. Bangladesh is not unique in the lack of domestic inputs for the RMG sector. In fact, the most successful RMG exporters in history — namely, Japan, Hong Kong SAR, the Republic of Korea, and Taiwan Province of China - all relied heavily on imports of raw materials and textiles in the early stage of their export drive. China, despite its large agriculture and textiles industries, also imports large volumes of raw materials and textiles. While lack of domestic inputs limits backward linkages to domestic industries, it is not necessarily a competitive disadvantage for the RMG sector as long as it can access inputs at world prices with short lead times. This points to the importance of an open import regime, trade facilitation, and infrastructure (see below).

39. The RMG sector has attracted only very limited foreign direct investment (FDI), most of which has gone to the export processing zones (EPZs), which contribute about 10-12 percent of total exports. Bangladesh's RMG sector was originally launched by foreign investors, mostly from the Republic of Korea and Hong Kong SAR, who were taking advantage of Bangladesh's export quotas in restricted markets, as well as an abundance of cheap labor. Over time, however, the role of FDI has become smaller because of problems in the business environment, including government restrictions. This has contributed to the slow diversification and upgrading of exports, giving low wages and quota access a greater role in maintaining competitiveness. Bangladesh mainly produces at the low end of the market (referred to as the "cut, make, and trim" segment), where value added and profit margins are low.

\section{B. Impact of Elimination of MFA Quotas}

40. With the elimination of MFA quotas, competition for global market share will intensify, with potentially significant consequences for Bangladesh. The Agreement on Textiles and Clothing in 1995 called for a gradual, staged phase-out of the quotas carried over from the MFA regime over a 10-year transition period. However, in practice the phaseout was heavily back-loaded. ${ }^{10}$ This is why the final stage of January 1,2005 , will have the

\footnotetext{
${ }^{10}$ See e.g., Francois and Woerz, 2005.
} 
largest consequences. Experience from the elimination of earlier quotas, model simulations, and exporters' relative success in quota-free markets all indicate that only a handful of countries may end up reaping the benefits of liberalization, in particular, China, India, and Pakistan. ${ }^{11}$ Specific model simulations for Bangladesh indicate that exports could fall substantially in the wake of quota removal. ${ }^{12}$

41. Nevertheless, the limited evidence so far indicates that RMG exports are holding up reasonably well in most low-income Asian countries, including Bangladesh. In most of these countries exports and orders have been better than expected, and business surveys also show some optimism that export volumes may remain at current levels in the short run. However, prices are weakening, and local industry associations still expect a significant eventual impact. ${ }^{13}$

\section{Although the RMG export growth in Bangladesh has moderated over recent} months, the knitwear sector continued to expand (in particular to the $E U$ ), compensating in part for the weaker performance of the woven garments sector (Figure 1). Bangladesh's knitwear sector enjoys several advantages over the other component of its RMG sector: (i) its technology confers a greater role to low-wage, unskilled labor; (ii) most of its raw materials are sourced locally or from the region, making it less difficult to meet rules of origin (ROO) in major export markets; (iii) greater availability of local inputs implies shorter lead times for orders. Available RMG export data for Bangladesh do not allow for a volume-price decomposition, but import data from Bangladesh for the US for the first quarter of 2005 still show a volume growth of 15.6 percent on a 12-months basis, and a price increase of 4.5 percent, which is actually a much better performance than in the first quarter of $2004 .^{14}$

\footnotetext{
${ }^{11}$ See for example, IMF, 2005 b.

${ }^{12}$ See Mlachila and Yang, 2004.

${ }^{13}$ See IMF, 2005a

${ }^{14}$ US Department of Commerce, Office of Textiles and Apparel; similar data for the EU are not available.
} 


\section{Exports}

(12-months change in percent of three-months moving average)

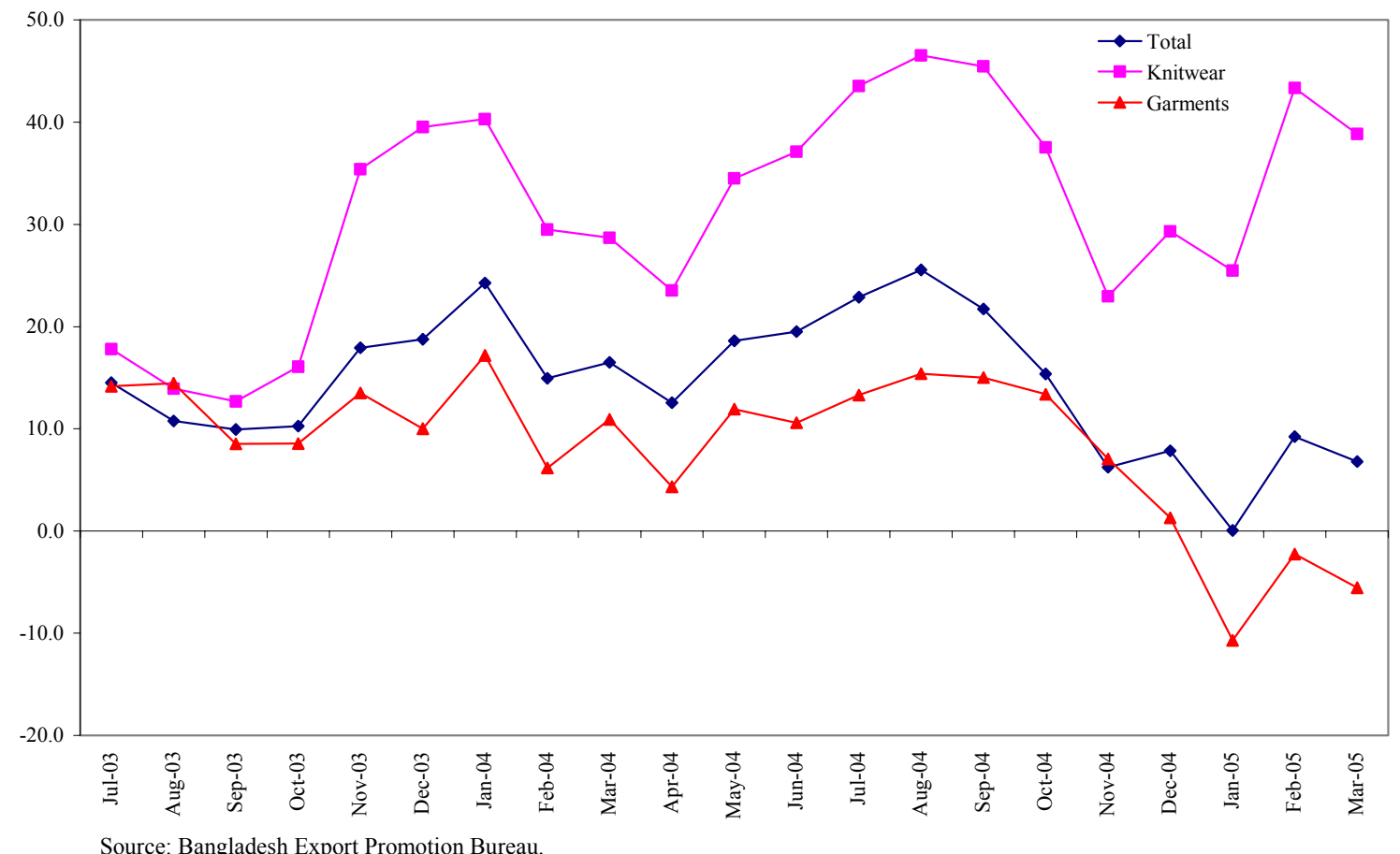

43. During the recent Article IV consultations in Bangladesh, staff discussions with private sector operators left the impression that RMG-export competitiveness may be better than previously assumed. No closing of factories or loss of jobs in the RMG sector have been observed so far. Private sector operators stated that they had not experienced a structural break in the RMG-export climate, in spite of the full MFA-quota phase out as of January 1, 2005. Recent order positions had held up well, and even some expansion plans in Bangladesh were reported (as opposed to plans in other countries). RMG activities in Bangladesh could also be consolidated to better compete with other regional RMG exports in the high-volume, low-margin segment of the world market, particularly as buyers are expected to keep their sources of supply at least somewhat diversified.

\section{The Bangladesh government has taken some welcome and important measures} to improve the competitiveness of the RMG sector. The flexible exchange-rate system provides a line of defence against the impact of the full elimination of MFA quotas. Regarding infrastructure, with the assistance of the AsDB, the capacity of the Chittagong port is being upgraded, which should help to reduce lead-times for RMG orders. The authorities are also working closely with the World Bank and AsDB to formulate a restructuring plan for the energy sector, which should help to alleviate electricity problems. An action plan of US\$40 million for the RMG sector is being finalized, to be financed by the donor community, mainly concentrating on the provision of training and marketing programs 
for potential displaced workers. The restrictions on FDI in the RMG sector outside the EPZs have recently been removed. ${ }^{15}$ Finally, Bangladesh is seeking duty-free access for RMG exports to the US market, together with other LDCs that are facing similar pressure from the removal of quotas (a bill to this effect currently lies with the US Senate). ${ }^{16}$

\section{Some temporary breathing space for Bangladesh's RMG sector is likely to be} created by the recent invoking of WTO safeguards with respect to China by the US, and subsequently the EU. It is imperative that this breathing space will be used to implement further actions to improve competitiveness. Under China's 2001 protocol of WTO accession, special anti-surge clauses for RMG products allow other WTO members to keep restrictions on China's exports for up to four years. On May 13, the US announced that it is invoking safeguards based on the magnitude of increases in RMG imports from China and China's significant capacity to increase production and exports to the US in three product categories (cotton knit shirts and blouses, cotton trousers, and cotton and man-made fiber underwear). This led to quotas limiting Chinese annual export growth to the US in these categories to 7.5 percent. More categories are under consideration. On May 23, the EU followed suit, launching safeguards consultations with China on two categories of RMG products (t-shirts and flax yarn). The possibility of further safeguard measures against China has led RMG importers to maintain a more diversified sourcing structure than they otherwise might have. However, it will only postpone the full force of Chinese competition, and not eliminate the increased competition from other countries. The Bangladesh government and RMG sector should thus make good use of the breathing space resulting from any safeguards measures.

\section{Medium-term Competitiveness}

46. Bangladesh's medium-term competitiveness, including that of the RMG sector, depends on the general business environment and ability to diversify the economy. Longer-term developments in the real effective exchange rate (REER) do not point to overall problems with external price competitiveness as the REER has been remarkably stable for over 20 years. Since the floating of the exchange rate in May 2003, the taka has depreciated by 9 percent and 5 percent in nominal and real effective terms. The relative stability of the taka during this long period was in part due to the rapid growth of RMG exports, and increasing remittances from Bangladesh's workers abroad. Together, these increases more than offset the trend decline in aid inflows relative to GDP, and were sufficient to balance increases in imports. The relatively favorable macroeconomic climate in Bangladesh has also contributed to exchange rate stability.

\footnotetext{
${ }^{15}$ These restrictions required potential investors to make a substantial investment in backwardly linked industries in order to be allowed to make an investment in the RMG sector.

${ }^{16}$ Since 2001, duty-free access to the EU has already been guaranteed through the Everything But Arms agreement, if ROO requirements are met. A relaxation of ROO requirements would provide additional support to the industry.
} 
47. However, a recent study on growth and export competitiveness by the World Bank identifies serious competitiveness problems, and lists Bangladesh as a worse performer than comparator countries on several components of the business environment. ${ }^{17}$ These problems center on infrastructure bottlenecks, weak governance, insufficient financing, inadequate labor quality, low FDI, and a trade regime that has an antiexport bias.

\section{Infrastructure bottlenecks}

48. Infrastructure bottlenecks related to power, telecommunications, and the road network significantly increase the cost of production, impede productivity growth, and hamper external competitiveness of Bangladeshi firms (Table 1). Only 31 percent of the population has access to power. Inadequate access to electricity was the most frequent complaint among firms surveyed for a recent investment climate assessment. ${ }^{18}$ For those with a utility connection, reliability is a major issue. Another significant source of the weak business environment is the lack of access to communications services. Teledensity (fixed and cellular) is far lower than in comparator countries. Even in regions that are within reach of the telephone network, access is made difficult by the extremely high cost involved in getting the initial connection. Despite a relatively dense road network, poor road conditions seriously impair private activity.

49. Poor port conditions are leading to lost economic potential, and are of particular importance for the RMG sector, given its large international trading volumes. The Chittagong port, which handles nearly 85 percent of the country's merchandise trade, is plagued by labor problems, poor management, and lack of equipment, a situation that is fairly symptomatic of the rest of the port system's problems as well. These problems are exacerbated by time consuming and cumbersome customs procedures that provide constant opportunities for bureaucratic discretion. Customs procedures at ports require more documents and take longer than at other regional ports. For the RMG sector, this implies the longest lead times for orders in the region (over 100 days), except for land-locked Nepal.

\section{Weak governance}

50. Bangladesh's business environment performs relatively badly on various indicators of governance. Most prominently, Transparency International has placed Bangladesh last on its cross-country corruption ratings for the last two years. In a recent survey, about 60 percent of firms surveyed viewed corruption as a major constraint to business operation and growth; lack of access to electricity was the only other constraint that was viewed as a major constraint by a higher number of surveyed firms. According to the World Bank's Doing Business 2003 database, although the number of procedures involved in starting a business in Bangladesh, and the time to clear these procedures, is relatively low,

${ }^{17}$ This section draws heavily on that study, World Bank, 2004a.

${ }^{18}$ See World Bank and Bangladesh Enterprise Institute, 2003. 
the cost of these procedures is extremely high as a percentage of per capita income (Table 2). Similarly, the cost of getting a business contract cleared and enforced is quite high. Tax administration is also identified as one of the main structural reforms of the authorities program, is singled out as a major problem area.

51. Further efforts are important to move the economy to a more friendly business environment. This implies addressing in particular the corruption and the law and order problems. Progress is very much dependent on strong political commitment. The central policy challenge is to create a broad, enabling business environment conducive to private investment. The government would need to define the rules of competition, strengthen the regulatory environment, and tackle the problem of poorly performing state-owned enterprises

\section{Insufficient financing}

52. Bangladesh has a relatively shallow financial sector, where weak governance and large nonperforming loans limit access to finance. Bank credit to the private sector and broad money as a percentage of GDP are relatively low. Deep-rooted institutional weaknesses drastically restrict the efficacy of the banking sector. Due to ineffectual management, political interference, and problems of corruption and directed lending, the four nationalized commercial banks (NCBs) are in a weak financial position.

\section{Inadequate labor quality}

53. While abundant low-wage labor may be Bangladesh's main competitive advantage, the relatively low productivity of that labor constrains the growth potential. Table 3 shows that, other than Sri Lanka, Bangladesh has the lowest productivity, using button-down shirts as a comparison, of any South Asian country. In this comparison of shirts per worker, it should be kept in mind that this measure could be substantially underestimating productivity in Sri Lanka, as its shirts are a high-value product. Similarly, since Bangladesh is mainly producing in the low end of the market, its productivity could in fact be overestimated by this measure. Although similar statistics for China are not available, anecdotal evidence suggests that value addition per worker in a Chinese RMG factory is more than twice that in a similar Bangladeshi factory. Furthermore, even after paying the higher wages and greater amounts of capital spending, a typical Chinese factory is still much more profitable than the comparable factory in Bangladesh. The relatively low productivity in Bangladesh is a cause of competitiveness problems, but at the same time at least to some extent reflects the structural problems mentioned above.

\section{Low FDI}

54. Another factor that at the same time can be viewed as cause and effect of competitiveness problems is the lack of FDI. Gross FDI inflows as a ratio to GDP in Bangladesh have been among the lowest in the world. This is at least partially related to the structural problems in the business environment mentioned earlier. The perception of widespread corruption likely features prominently among these. The lack of FDI has meant that Bangladesh has missed out on the positive technology spillovers that it usually provides. 
It is also a well-established stylized fact that foreign firms in LICs generally have higher (labor) productivity and wages than domestic firms.

\section{Anti-export bias in trade regime}

\section{A lack of openness in Bangladesh's trade policy has also hindered}

competitiveness. This has been a particular problem for the outward-oriented RMG sector, with its high import content. Although commendable progress has been made in trade liberalization, Bangladesh still has the most protected economy in South Asia and one of the most protected worldwide, ${ }^{19}$ implying considerable anti-export bias. While tariffs were reduced and streamlined, a complex structure of duties and exemptions increases effective protection (Table 4). Furthermore, Bangladesh remains the only country in South Asia with some traditional quantitative restrictions still in place. Thus the costs of inputs are raised for the RMG sector.

56. Furthermore, customs procedures are cumbersome, and the duty-drawback system is functioning badly, further raising business costs. In particular the latter acts as a constraint on diversification. Unlike the RMG sector, exporters who do not/cannot access the duty-free bonded warehouse system or EPZs, or who acquire specific inputs paying import duties or domestic taxes, can benefit from the duty-drawback system managed by the Duty Exemption and Drawback Office (DEDO). However, despite various attempts to improve DEDO's governance and efficiency through staff training, new technical staff, and strengthened reimbursement procedures, this office still remains weak in governance, and inefficient in disbursing rebates, as reflected in significant delays in payments of tariff/tax rebates. This is partly due to the complexity of the existing import duty regime, and a very lengthy duty drawback process involving the determination of input-output coefficients and the submission of 18 documents by direct exporters (even more documents in the case of indirect exporters).

57. In trade policy, significant progress has been made in the FY05 budget. Key measures include a substantial reduction in the level and dispersion of customs and supplementary duties. The number of products subject to quantitative restrictions was also halved with effect from April 2005, together with a reduction in the number of regulatory stages involved in import and export. In addition, the authorities intend to remove the remaining quantitative restrictions on imports, except those on grounds of religion, health, security, and the environment, by June 2005.

58. The key objectives of future trade reform should be: further simplification of the import tax regime; reduction in the dispersion and average level of nominal (and thus

\footnotetext{
${ }^{19}$ See World Bank, 2004b; note that this assessment was made before the most recent lowering and streamlining of tariffs, in the context of the budget for the FY05, which brought down the top customs-duty rate to 25 percent, moved to three-tier non-zero tariffs, and significantly scaled down supplementary duties.
} 
effective) protection (merging para-tariffs with customs duties), preferably through a preannounced medium- and long-term schedule of tariff reductions (as done recently by India), and the elimination of any remaining trade-related quantitative restrictions. Furthermore, DEDO would need to be effectively reformed, in order to make the duty-drawback system function efficiently. To protect government revenues, parallel progress is required in expanding the base of VAT and direct taxes, while strengthening tax administration.

\section{Conclusion}

\section{The full elimination of MFA quotas on January 1, 2005 will lead to increased} competition and repositioning in the world RMG market. Bangladesh must face this challenge by taking measures to improve competitiveness, both with a view to maintain the RMG-export market share and to diversify its export structure. Bangladesh could continue to benefit from the abundance of low-cost labor, but it must also address a host of competitiveness problems, mainly in infrastructure, governance, finance, labor quality, FDI, and trade policy, if the economy is to keep up with comparator countries. It is imperative to make good use of the breathing space resulting from any safeguards measures against China, before the full force of its competition is unleashed. The investment regime should be further liberalized to support export diversification, supported by reducing supply constraints and promoting non-RMG exports over the medium term. 
Table 1. Infrastructure Indicators: Cross-Country Comparisons

\begin{tabular}{lrrrr}
\hline & $\begin{array}{r}\text { Electricity } \\
\text { Generating } \\
\text { Capacity }\end{array}$ & $\begin{array}{r}\text { Telephone } \\
\text { Mainlines } \\
\text { (Kw per capita) }\end{array}$ & $\begin{array}{r}\text { Total Road } \\
\text { Networks } \\
\text { (per 1000 people) }\end{array}$ & $\begin{array}{r}\text { Paved Roads } \\
\text { (percent of total } \\
\text { roads) }\end{array}$ \\
\hline Bangladesh & 0.03 & & & \\
Chile & 0.63 & 5.3 & 1.6 & 9.5 \\
China & 0.25 & 247.8 & 0.1 & 18.9 \\
India & 0.11 & 43.8 & 0.1 & 22.4 \\
Indonesia & 0.10 & 65.7 & 1.1 & 45.7 \\
Malaysia & 0.58 & 509.9 & 0.2 & 46.3 \\
Niger & $\ldots$ & 2.1 & 0.2 & 75.8 \\
Sri Lanka & 0.09 & 79.9 & 0.0 & 7.9 \\
Thailand & 0.34 & 221.9 & 1.5 & 95.0 \\
Vietnam & 0.06 & 53.0 & 0.1 & 97.5 \\
& & & 0.3 & 25.1 \\
\hline
\end{tabular}

Source: World Bank.

Table 2. Cost of Doing Business: Bangladesh vs. Comparator Countries

\begin{tabular}{|c|c|c|c|c|c|c|c|c|}
\hline \multicolumn{5}{|c|}{ Starting a Business } & \multicolumn{4}{|c|}{ Enforcing Contracts } \\
\hline & $\begin{array}{l}\text { Number of } \\
\text { Procedures }\end{array}$ & $\begin{array}{r}\text { Duration } \\
\text { (Days) }\end{array}$ & $\begin{array}{r}\text { Cost } \\
\text { (US\$) }\end{array}$ & $\begin{array}{r}\text { Cost } \\
\text { (percent of } \\
\text { GNI per } \\
\text { capita) }\end{array}$ & Number of Procedures & $\begin{array}{r}\text { Duration } \\
\text { (Days) }\end{array}$ & $\begin{array}{r}\text { Cost } \\
\text { (US\$) }\end{array}$ & $\begin{array}{r}\text { Cost } \\
\text { (percent } \\
\text { of GNI } \\
\text { per } \\
\text { capita) }\end{array}$ \\
\hline Bangladesh & 7 & 30 & 272 & 75.5 & 15 & 270 & 973 & 270.3 \\
\hline Chile & 10 & 28 & 494 & 11.6 & 21 & 200 & 626 & 14.7 \\
\hline China & 11 & 46 & 134 & 14.3 & 20 & 180 & 301 & 32 \\
\hline India & 10 & 88 & 239 & 49.8 & 11 & 365 & 456 & 95 \\
\hline Indonesia & 11 & 168 & 103 & 14.5 & 0 & 225 & 1910 & 269 \\
\hline Malaysia & 8 & 31 & 959 & 27.1 & 22 & 270 & 687 & 19.4 \\
\hline Niger & 11 & 27 & 759 & 446.6 & 29 & 365 & 97 & 57.1 \\
\hline Sri Lanka & 8 & 58 & 154 & 18.3 & 17 & 440 & 64 & 7.6 \\
\hline Thailand & 9 & 42 & 144 & 7.3 & 19 & 210 & 586 & 29.6 \\
\hline Vietnam & 11 & 63 & 129 & 29.9 & 28 & 120 & 37 & 8.5 \\
\hline Global Median & 10 & 45 & 541 & 24.3 & 21 & 225 & 352 & 12 \\
\hline
\end{tabular}

Source: World Bank. 
Table 3. Labor and Productivity Comparisons

\begin{tabular}{lrrr}
\hline & $\begin{array}{r}\text { Unit Labor } \\
\text { Costs } \\
\text { (US\$/shirt) }\end{array}$ & $\begin{array}{r}\text { Wages } \\
\text { (US\$YYear) }\end{array}$ & $\begin{array}{r}\text { Productivity } \\
\text { (Shirts/Worker/Year) }\end{array}$ \\
& & & \\
Bangladesh & & & 2536 \\
India & 0.11 & 290 & 2592 \\
Pakistan & 0.26 & 668 & 7100 \\
Sri Lanka & 0.43 & 1343 & 719 \\
& 0.79 & 570 & \\
\hline
\end{tabular}

Source: World Bank

Table 4. Rankings of Average Tariffs in South Asia in Relation to Average Tariffs in Other Developing Countries

(from most to least protectionist)

\begin{tabular}{lrrr}
\hline & All Products & Manufacturing and Others & Agriculture \\
& & & \\
Bangladesh & 5 & 7 & 10 \\
India & 10 & 12 & 7 \\
Pakistan & 15 & 18 & 26 \\
Sri Lanka & 42 & 20 & 12 \\
Nepal & 22 & & 42 \\
& & 20 \\
\hline
\end{tabular}

Source: World Bank. 


\section{REFERENCES}

Francois, Joseph and Julia Woerz, 2005, "Rags in the High Rent District: Rhetoric and Reality in the Elimination of Textile and Clothing Quotas," manuscript.

International Monetary Fund, 2005a, "Expiry of Textiles Quotas: the Impact on Asia, AsiaPacific Regional Outlook," Special Feature (Washington, D.C.).

— 2005b, "The Ending of Global Textile Trade Quotas," World Economic Outlook, Box 1.3 (Washington, D.C.).

Mlachila, Montfort and Yongzheng Yang, 2004, “The End of Textiles Quotas: a Case Study of the Impact on Bangladesh," IMF Working Paper No. 04/108 (Washington D.C.: International Monetary Fund).

World Bank, 2004a, Bangladesh: Growth and Export Competitiveness.

— 2004b, Trade Policies in South Asia: an Overview.

World Bank and Bangladesh Enterprise Institute, 2003, Improving the Investment Climate in Bangladesh. 


\section{Key Medium-Term Fiscal Challenges ${ }^{20}$}

60. Bangladesh's economic performance and social indicators strengthened during the 1990s, due mainly to reform measures adopted early in the decade. Real GDP growth accelerated to an average of about 5 percent, from 4 percent in the 1980s, and inflation was moderate. Fiscal policy was cautious, with public debt contained at around 50 percent of GDP. However, structural fiscal problems have kept revenue and public expenditure below the path needed for faster reduction in poverty. Total revenue stagnated well below 10 percent of GDP during the 1990s, and barely exceeded this threshold in the early 2000s, putting Bangladesh among the countries with the lowest total revenue-to-GDP ratio. Such a low level of revenue has severely constrained expenditure. Total spending is also among the lowest in the world, fluctuating in the range of 11-15 percent of GDP in the last decade, with ADP averaging about 5.5 percent of GDP.

61. In view of the exceptionally low revenue mobilization and the pressing need to step up development spending, Bangladesh is facing major medium-term fiscal challenges. To address these challenges, the medium-term fiscal strategy should be centered on boosting revenue performance and reorienting expenditure to better support growth and the MDGs, while, at the same time, protecting fiscal sustainability. This paper discusses the main challenges in the areas of revenue (Section A) and expenditure (Section B). Section C summarizes the main conclusions of the paper.

\section{A. Key Challenges in Tax Administration and Policy}

\section{Near-term revenue issues and priorities}

62. Efforts toward addressing tax administration and policy issues bear directly on economic governance, which requires strong political commitment in support of the NBR. A good start has been made to address major weaknesses in tax administration and policy. In particular, the large taxpayer unit (LTU) for income tax and the Central Intelligence Cell (CIC) started operation in late 2003, followed by the LTU for VAT in late 2004. To improve the compliance of taxpayers, a system of universal self-assessment for LTU income taxpayers has been introduced, together with higher penalties for late and nonfiling. At the same time, the audit program is being strengthened and expanded. The tax base has also been broadened through inclusion of more services in the VAT net.

\section{Steps have also been taken in the FY05 budget to start reducing and} rationalizing import tariffs and supplementary duties. For customs duties, a three-tier structure, with a maximum rate of 25 percent was introduced. For supplementary duties, the number of rates has been reduced from seven to three, and the maximum normal rate reduced to 30 percent; higher rates have been maintained for luxuries and special items (automobiles, and arms and ammunition). In the area of customs administration, the use of information technology has increased efficiency and transparency. Assessment and clearance of goods are

\footnotetext{
${ }^{20}$ Prepared by Bernardin Akitoby (FAD).
} 
now undertaken through the Automated System for Customs Data (ASYCUDA++) computer system. At the same time, the valuation of goods and the post-clearance audit are being improved, with the gradual introduction of risk-based checking process and audit.

64. The near-term priorities should be to ensure the effectiveness of the LTU system and to further modernize the customs administration. On the LTU, particular attention should be given to improving the operations of the income tax and VAT LTUs. To this end, with World bank and DFID assistance, the audit functions need to be revamped through (i) development of an information sharing system between the CIC and the LTU's audit wing; (ii) adequate staffing with sufficiently skilled audit officers; (iii) implementation of training program; and (iv) conducting joint audits for large taxpayers of the LTU system. To further increase audit effectiveness, an independent member audit position in the NBR, reporting directly to the chairman, would be created. The tax collection enforcement wing also need to be strengthened through adequate staffing and training, as well as improvement in arrears monitoring system and collection procedures, including expediting disposal of court cases. Finally, consideration should be given to developing an appropriate incentive system to promote good performance and penalize inappropriate behavior of tax officials.

65. Customs operations should be further modernized with a view to detect undervaluation of imports and improve customs collections. To this end, key actions would include (i) strengthen the customs valuation process and the post-clearance audit; (ii) introduce more comprehensive audits; (iii) ensure adequate training of inspectors; and (iv) develop an anti-smuggling program. Further steps are also needed to minimize abuses of the special bonded warehouses and the duty drawback scheme.

\section{Medium-term revenue issues and priorities}

\section{NBR modernization}

66. On tax administration, the focus will be on the NBR modernization plan, assisted by the World Bank under the Development Support Credit. International experience suggests that most revenue boards have been moving away from a tax-type structure, which is still operating in Bangladesh. Such a structure presents serious weaknesses, including duplication of functions, uncoordinated audit and collection actions, poor taxpayer services, and inconsistent priorities between taxes. Following FAD and World Bank technical assistance, the authorities are working on a medium-term strategy to modernize the NBR, with a view to fundamentally improve governance. Supported by a new human resource policy ${ }^{21}$ and an information technology strategy, the NBR modernization plan should include the following components: (i) reorganization of the NBR along functional lines to permit clear lines of accountability; (ii) adoption of a true self-assessment system to reduce discretion of tax officials; (iii) establishment of a risk-based auditing system

\footnotetext{
${ }^{21}$ The main elements of the human resource policy could include a new recruitment policy, a new wage policy, a training plan, and an anti-corruption strategy.
} 
supported by third-party information; and (iv) introduction of a unique taxpayer identification number (TIN).

\section{Functional organization}

67. A move to a functional structure is key to transforming the NBR into a modern and efficient administration. International evidence suggests that the functional organization offers a number of advantages. First, it improves taxpayer services by providing a single point of access for taxpayers. This enables taxpayers to easily understand their rights and obligations, thus improving compliance. Second, the functional model also improves productivity through greater cohesiveness and synergies among the internal functions. For example, comprehensive multi-tax audits can be carried out, leading to cost reduction. Similarly, enforcement operations can be conducted for all taxes owed by the same taxpayer.

68. Complete implementation of a functional structure should be viewed as a longterm project that needs to be steered by a dedicated management team. More importantly, a long-term commitment from the government at the highest level is critical to the sustainability of the modernization process. As a first step, a functional organization should be introduced in the LTUs where modern structures, processes, and technology can be trialed easily. It could be followed by the centralization of the audit and collection functions at the NBR level under newly created member positions, as well as independent units for human resources and information technology policies.

\section{Self-assessment}

69. Self-assessment is a key foundation of modern tax administrations. Under a selfassessment system, taxpayers should determine, report, and pay their own tax liabilities, based on the premise that they are best placed to know their tax liabilities. This will allow tax administrations to devote their limited resources to countering tax evasion. International experience shows that a number of prerequisites should be in place for the successful implementation of a self-assessment system. These include: (i) simple tax laws and procedures to reduce compliance costs; (ii) efficient and accessible taxpayer service to assist taxpayers to meet their obligations; (iii) effective audit and collection enforcement that detect promptly taxpayers that fail to comply with tax laws; (iv) strong but fair penalty systems to signal that tax fraud will be prosecuted to the fullest extent of the law; and (v) access to independent review of decisions to protect taxpayers' rights.

70. Most of these preconditions are not currently met in Bangladesh ${ }^{22}$. With DFID technical assistance, steps have been taken to redraft tax laws (e.g., income tax law), but further actions are needed to simplify tax laws and procedures and reduce compliance costs.

\footnotetext{
${ }^{22}$ Ideally, all the prerequisites for self-assessment should be addressed in parallel. However, given the technical capacity constraints at the NBR, priority should be given to developing effective and accessible taxpayer service, as well as strengthening audit and collection operations.
} 
In the meantime, efforts have been made to develop taxpayer services in the LTU system, but the capabilities of this unit should be beefed up through training. The audit and collection functions need to be revamped, first in the LTU system as outlined in the near-term priorities. The penalty system for noncompliance was stiffened in 2004 , and early evidence points to improved compliance as a result of this change. Taxpayers have access to independent review of tax decisions and can go to tax appellate tribunals to get redress for their grievances, but the process is regarded as ineffective.

71. Bangladesh's Revenue Commission, established in 2003 with representatives of the government and private sectors, issued its report that proposes a true selfassessment be introduced for all tax returns. Given the status of the prerequisites for successful self-assessment system, it would be advisable to view a general introduction of self-assessment as a medium-term objective. As an interim step, a self-assessment system should be implemented and trialed in the LTU. Once sufficient experience has been gained and the basic preconditions have been put in place, a full self-assessment system at the NBR level should be considered.

\section{Risk-based audit system}

72. A self-assessment system needs to be supported by a strong risk-based auditing system. An effective audit program should contribute to better tax compliance by making taxpayers aware that not complying with tax laws will result in sanctions. Taxpayers' perception of the probability of being audited strongly influences their degree of compliance. Since risk-based auditing does not seek to audit all taxpayers, scarce resources should be targeted at the taxpayers most likely to be evading their tax liabilities.

\section{Unique taxpayer identification number}

73. The introduction of a unique taxpayer identification number (TIN) is critical to the reform of tax administration and a prerequisite to a successful computerization of tax processes. Country experiences suggest that, without a unique TIN for all taxes, it would be difficult to have a single administration responsible for the enforcement of compliance with all tax laws. Both the income tax and VAT laws currently require the use of an identification number. However, in practice, a number of factors have compromised the identification system.

- $\quad$ First, the income tax and VAT departments have developed their own identification systems independently, ${ }^{23}$ which complicates the cross-checking of taxpayers' compliance.

\footnotetext{
${ }^{23}$ The identifier is called taxpayer identification number for income tax, and business identification number for VAT.
} 
- $\quad$ Second, the lack of a systematic system to deregister both VAT and income tax registrants has complicated tax operations and reduced the relevance of the identifier for detecting noncompliant taxpayers.

- Third, fraudulent acquisition of identifiers has contributed to tax avoidance. Moreover, the reliability of the business identification number (BIN) for VAT has also been compromised by the fact that each branch of an enterprise is required to have its own BIN.

In light of these weaknesses, consideration should be given to consolidating the two taxpayer identification numbers (BIN and TIN) at the early stage of the modernization plan.

\section{Tax policy}

74. The priorities should be to expand the tax base and rationalize the complex tax system. The tax system in Bangladesh entails relatively high tax rates and numerous exemptions. This system is prone to corruption and tax evasion and gives rise to economic distortions, especially through high trade taxes. Thus, the tax system needs to be rationalized and its efficiency improved. The emphasis over the medium term should be on: (i) widening the VAT and income tax bases, mainly by reducing exemptions and the scope of tax holidays; and (ii) further reducing and rationalizing import tariffs and supplementary duties, while identifying alternative revenue sources to protect revenue.

\section{Widening the VAT and income tax bases}

75. A fundamental review of tax exemptions should be undertaken, with a view to reducing them drastically. In particular, the tax base should be broadened by covering more product/services and eliminating numerous exemptions, as recommended by Bangladesh's Revenue Commission Report (BRCR). On income tax, the most critical problem remains the erosion of the tax base through the tax holiday facility. As recommended by BRCR, tax holidays should be abolished and replaced by a simplified system of depreciation allowances $^{24}$.

\section{Reducing and rationalizing import tariffs and supplementary duties}

\section{Building on the steps taken in the FY05 budget, the process of reduction and} rationalization of customs duties should continue, with the pace of reform dictated by progress in strengthening and broadening the domestic tax base, so that revenue is protected. Priority should be given to the reduction of multiplicity of levies. As pointed out by BRCR, there are currently as many as 9 separate levies at the customs, which lead to the lack of clarity, simplicity, and transparency. While it is beyond the scope of this study to provide specific tax policy advice, consideration should be given to BRCR's various proposals for

\footnotetext{
${ }^{24}$ It is expected that the existing tax holiday facility will be allowed to lapse at end-June 2005 and will be replaced by a more rational system for investment incentives.
} 
dealing with each of these levies ${ }^{25}$. It would also be useful to first consolidate the supplementary duties into statutory duty regime and then reduce them gradually.

\section{B. Key Challenges in Expenditure Management and Policy}

77. The key issues in expenditure management and policy include inefficiency in and weak monitoring of the ADP, insufficient spending on maintenance, and structural weaknesses in employment and wage policies. In light of these issues, reform priorities should focus on improving the prioritization and efficiency of current spending and ADP, as well as reforming the civil service.

\section{ADP-Main issues and policy options}

\section{Main issues}

78. The government's PRSP stresses that efficient implementation of the ADP is key to achieving faster poverty reduction. Numerous World Bank's studies and the government-appointed Expenditure Review Commission conclude that there is considerable scope for improving the selection, prioritization, and implementation of ADP projects, which average 5.5 percent of GDP a year. The main weaknesses are summarized in the World Bank's Public Expenditure Review (2003, p. 16): “The ADP includes a significant number of projects with a questionable rationale, low priority for public investment, or doubtful viability or equity. Questionable projects regularly find their way into the ADP mainly because of the weaknesses in the system of project management: (i) insufficient scrutiny of projects; (ii) weak capacity in project selection, design, and implementation; (iii) overly long periods for project implementation; and (iv) the political imperative of satisfying numerous demands through an excessive number of small projects."

79. Deficiencies in the procurement procedures ${ }^{26}$ have also undermined the ADP's effectiveness and led to low absorption rates of external concessional financing. As pointed out by the 2003 fiscal ROSC for Bangladesh, in recent years ADP projects in transport, shipping, and telecommunications have been increasingly financed through suppliers' credit obtained on nontransparent terms that circumvent competitive bidding processes. Moreover, procurement processing is too prolonged, often due to interferences by interest groups and lack of knowledge and skills at the working level.

\footnotetext{
${ }^{25}$ The Bangladesh Revenue Commission Report recommends that there should be only four types of levies at the customs point. These include (i) customs duty, (ii) value added tax, (iii) supplementary duty, and (iv) WTO prescribed anti-dumping duty, countervailing duty, or safeguard duty.

${ }^{26}$ Procurement issues are discussed in the World Bank's Country Financial Accountability Assessment (World Bank, 2000) and the Country Procurement Assessment Report (World Bank, 1999).
} 


\section{Policy options}

80. The government has started to tackle these weaknesses. Efforts have been made to strengthen project selection and execution in the line ministries. With AsDB's assistance, steps have been taken to streamline the project approval process, with a view to reducing project start-up delays. AsDB noted that greater attention to project implementation is yielding results, as evidenced by the fact that all 2004 ADB loans have become effective by early 2005 . To enhance transparency and efficiency in project implementation, new procurement regulations were introduced in 2003, and a new procurement law is being finalized, with the World Bank's assistance under the DSC. Moreover, a medium-term budget framework is being established in four key line ministries to ensure that pro-growth and pro-poor spending is given priority.

81. Despite these recent efforts, more needs to be done if Bangladesh is to sustain growth and reduce poverty. In the area of project selection, there is a need to improve investment planning and budgeting by adopting a medium-term expenditure framework and well-established criteria for evaluating public investments, and by integrating revenue and development budgets. Priority should be given to "core" projects that have the greatest impact on poverty reduction and contribute the most to social welfare. The recurrent cost implications of new investment should be incorporated in investment decisions. As regards project implementation, more improvement is needed in a number of areas. There is a need to strengthen mechanisms for monitoring project execution and ex post evaluations. This could help draw lessons from any implementation problems to ascertain the scope for cost-savings in future projects. With the introduction of new procurement guidelines, there is also an urgent need to train personnel involved in the procurement process and strengthen procurement management in line ministries and executing agencies.

\section{Government employment and pay-issues and policy options}

\section{Main issues $^{27}$}

82. The wage bill claims a relatively high share of the consolidated budget. The estimated wage bill for all employees supported by the consolidated budget in FY04 amounts to about 24 percent of central government spending, compared to an average of 15 percent for South Asia and 20 percent for countries with PRGF-supported programs. However, at about 4 percent of GDP, the government wage bill is below the average for South Asia (4.6 percent) and countries with PRGF-supported programs (4.8 percent).

83. The structure of the salary scale is not conducive to attracting and retaining skilled personnel. First, Bangladesh's civil service has a deeply entrenched tradition of incremental pay increases based on the length of service. This has undermined the development of a high-quality and accountable senior civil service. Second, average compensation for officers has fallen in real terms (ranging from 2 to 34 percent depending on

\footnotetext{
${ }^{27} \mathrm{An}$ analysis of government employment is not possible because of data deficiencies.
} 
the grade levels) since the last pay award in 1997. In addition, average wages for skilled government personnel are well below than of their counterparts in the private sector. Third, the structure of the pay scale has deteriorated continuously and the existing pay scale has become more compressed. The compression ratio (defined as the ratio of the highest to lowest grade wage) is currently at 6.4. International experience suggests that a ratio lower than 12 indicates an overly compressed wage scale.

\section{Policy options}

84. It is important that the authorities soon adopt a plan to reform the civil service with World Bank assistance. Reform of government employment and pay would help improve efficiency while containing the growth in the wage bill. Government employment should be rationalized through a comprehensive review of the size, function, and staffing of all government agencies.

\section{The reform in the government pay scale should adhere to four basic principles.}

- $\quad$ First, the pay scale needs to be decompressed gradually to facilitate the recruitment and retention of skilled personnel. In reforming the pay structure, the government needs to be mindful of the impact of the decompression on the average wage and the wage bill.

- $\quad$ Second, to the extent possible, appropriate private sector wage comparators should be used in setting public wages for highly skilled personnel. However, such an exercise must take into account all aspects of compensation (including in-kind and nonmonetary benefits) and the greater job security in the public sector. International evidence suggests that public sector wage could fall to about 80-90 percent of the private sector average and still be competitive.

- $\quad$ Third, it would be advisable to gradually merge all in-kind benefits and allowances into the pay scale before reforming the pay structure. This measure would improve budgetary transparency and decision making, while contributing to fairness in government compensation across sectors. Moreover, it would broaden the income and social security tax base.

- $\quad$ Fourth, the government should establish a tighter link between pay and performance, to provide incentive to workers for improving efficiency and productivity. Wage policy should be based on transparent rules, such as minimum time-in-grade requirements and objective criteria for promotion. Moreover, salary increases should be tied to a system of performance evaluation, and any incremental pay increase based on the length of service should be avoided.

\section{Conclusion}

86. While the fiscal stance has been broadly prudent over the past decade, the pace of structural fiscal reform has been disappointing. Weak governance has permeated most aspects of public resource management. As a result, Bangladesh is facing major fiscal 
challenges of strengthening revenue mobilization, improving ADP management, and reforming the civil service. In the area of revenue mobilization, the short-term priority is to ensure the effectiveness of the LTU system, while the medium-term focus should be on modernizing the NBR, expanding the tax base, and simplifying the complex tax system. Major and sustained effort will be required to increase the efficacy of ADP through better project selection and effective mechanisms to ensure transparency and accountability. Reforming the civil service is critical to progress in all other reform fronts. All these challenges need to be addressed in a timely manner if the country is to meet the MDGs by 2015, while preserving fiscal sustainability. Technical assistance in key areas would also be critical to help building capacity in carrying out the needed reforms (Table 1). 
Table 1. Bangladesh: Fiscal Reform Priorities

Tax administration

Make the LTU for VAT fully effective

Short term

Make the LTU system fully effective

Short term

Make the CIC fully effective

Develop risk-based criteria for selection of audit cases

Short term

Develop an HR strategy and measures to address corruption

Short term

Introduce unified taxpayer identification numbers

Medium term

Develop and implement NBR modernization strategy

Medium term

Medium term

Tax policy

Removal of tax holidays

Short term

Reduce VAT exemptions

Short term

Review of tax policy

Medium term

Expenditure policy

Develop core ADP, focusing on essential projects

Reorientation of public expenditure to support growth and MDGs

Short term

Civil service reform

Short term

Medium term

Expenditure management

Develop an accountable medium-term budget

Short term

Integrate revenue budget and development budget

Medium term

Streamline project selection and improve selection criteria

Short term

Source: Fund staff's assessment. 


\section{REFERENCES}

Bangladesh, 2004, Final Report of the Revenue Commission (Dhaka).

International Monetary Fund, 2003, Report on the Observance of Standards and CodesFiscal Transparency Module (Washington, D.C.).

World Bank, 2003, Bangladesh—Public Expenditure Review (Washington, D.C.).

—_, 2000, Country Financial Accountability Assessment (Washington, D.C.).

—, 1999, Country Procurement Assessment (Washington, D.C.). 


\section{Banking Reform in Bangladesh-A South ASIAN Perspective ${ }^{28}$}

87. This chapter examines bank reform in Bangladesh in comparison to India, Pakistan, and Sri Lanka. Section A provides an overview of the banking systems in all four countries. Section B examines the progress achieved in the areas of financial liberalization, prudential control and supervision, bank restructuring, and divestment of NCBs. Section C considers additional areas of reform that will be needed to further modernize banking systems in South Asia.

\section{A. Overview}

88. The banking systems of Bangladesh, India, Pakistan, and Sri Lanka have historically been characterized by low levels of intermediation, weak competitive environments, and tight state control over banking activities, often manifested by government ownership of the largest banks. These banks maintained extensive branch networks that accepted deposits from individuals, firms, and various levels of government, as well as remittances from abroad. The deposits were then converted into loans to large commercial firms and SOEs, import advances, or used to purchase government securities. Consumer credit, housing and auto finance, and lending to small- and medium-sized enterprises, key staples of activity for many banks in advanced economies, were insignificant, though efforts to promote these market segments have gained good traction in recent years.

89. The early emphasis on state-led banking reflected the need for governments to actively pursue industrial policies to engender growth. State-owned banks were regarded as the appropriate vehicles by which to channel savings to sectors of the economy with the best growth prospects. Moreover, it was frequently presumed that state-owned banks were necessary to provide banking services to rural areas, both by mobilizing rural deposits, and by providing credit to risky sectors like agriculture.

90. On balance, however, the historically dominant role of state-owned banks undermined financial sector development and impeded economic growth. In general, state-owned banks, or NCBs as they are called in Bangladesh, suffered from poor management, political interference, and an apathetic business culture that stressed protocol over innovation and customer service. Loans were frequently doled out to politically connected firms and individuals, with little subsequent oversight. Moreover, NCBs often made loans to unprofitable SOEs on noncommercial terms and with little expectation of repayment.

\footnotetext{
${ }^{28}$ Prepared by Peter Berezin (APD).
} 
91. Consequently, the equity of NCBs was often deficient, forcing governments to provide periodic capital injections and their respective central banks to provide regulatory forbearance for capital adequacy. Additionally, the implicit government guarantee on deposits in NCBs created an uneven playing field for private banks, which made it difficult for them to attract savings on favorable terms. As a result, private banks had to offer a premium over state-owned banks on deposit rates, which impaired profitability and at times forced private banks to lend to risky customers to generate a sufficiently high return to cover their cost of funds.

92. However, the past decade has seen momentous changes in banking systems across South Asia. The general trend has been towards liberalization and privatization, driven by growing disillusionment with the performance of NCBs, and burgeoning crosscountry evidence that financial liberalization leads to higher economic growth and lower financial sector vulnerabilities (La Porta, 2002). This has created more vibrant banking systems and increased bank intermediation, as evidenced by the pronounced upward trend in monetization in all four countries. Furthermore, with the growth of microcredit institutions, vulnerable groups have increasingly been able to gain access to finance without recourse to NCBs.

\section{M2 as Percent of GDP}

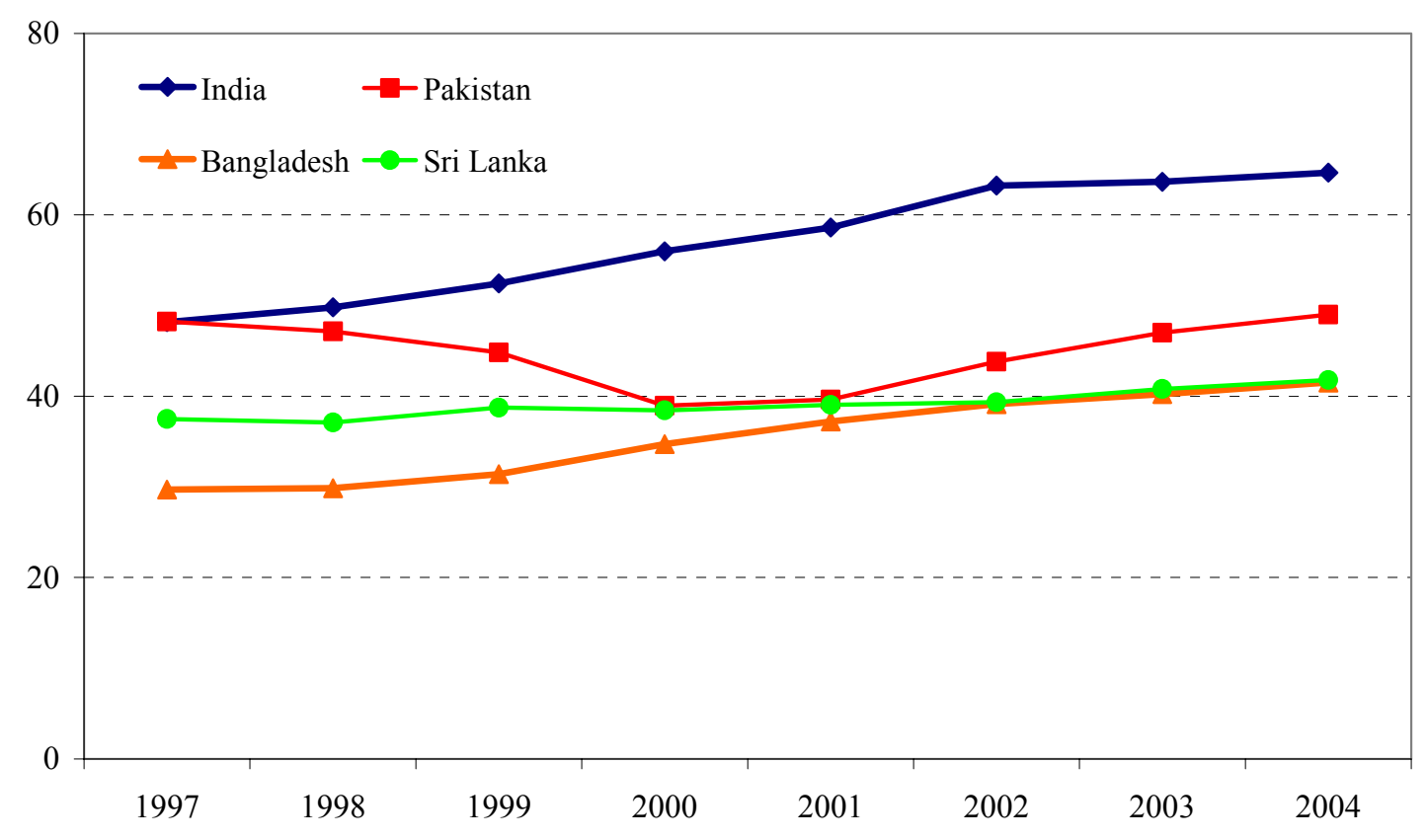

Source: Fund Staff estimates. 


\section{B. Recent Areas of Reform}

93. The reform agendas pursued by Bangladesh, India, Pakistan, and Sri Lanka have all differed in important ways, especially with regards to the pace and scope of efforts to restructure and divest state-owned banks. However, a common set of elements can be identified:

\section{Financial liberalization}

94. All four countries have to varying degrees taken steps to liberalize their banking systems. This has entailed:

- Reducing interest rate controls on lending and deposit rates. Interest rate ceilings often have the perverse effect of reducing lending to the targeted sector, especially to the smaller and riskier companies within that sector. All four countries have made significant headway in liberalizing interest rates. India, for example, has largely deregulated interest rates except for savings deposit accounts, nonresident Indian deposits, small loans up to Rs 2 lakh $(\$ 4,500)$, and export credit. However, banks in South Asia continue to be subject to occasional moral suasion by governments and central banks. This is particularly true with regards to lending rates to priority sectors, such as agriculture.

- Curtailing directed credit to favored sectors or industries. Though explicit targets for lending to priority sectors have become less common, they continue to exert an influence over bank decision making. The Reserve Bank of India (RBI), for example, requires that domestic Indian banks make 40 percent of their loans to priority sectors selected by the government. NCBs in Bangladesh are also expected to lend aggressively to the agriculture and export sectors.

- Lowering barriers to entry in the banking sector, especially to foreign banks. On balance, the market share of foreign banks in South Asia continues to be small, with much of their activities confined to providing banking services to multinational clients. However, recent policy initiatives have striven to create a more favorable environment for foreign banks. The State Bank of Pakistan, for example, has eased branch licensing policy and eliminated absolute restrictions on the number of foreign banks. India has increased the limit on foreign ownership from 49 percent to 74 percent of bank equity and now allows foreign banks to set up local subsidiaries. However, foreign banks are not permitted to acquire local banks unless the bank in question has been designated as a weak bank by the RBI. In Bangladesh, foreign banks are permitted to operate freely, although their market share remains low, and no foreign bank has endeavored to build a large branch network. 
Foreign Commercial Bank Share of Banking System Assets

(Percent)

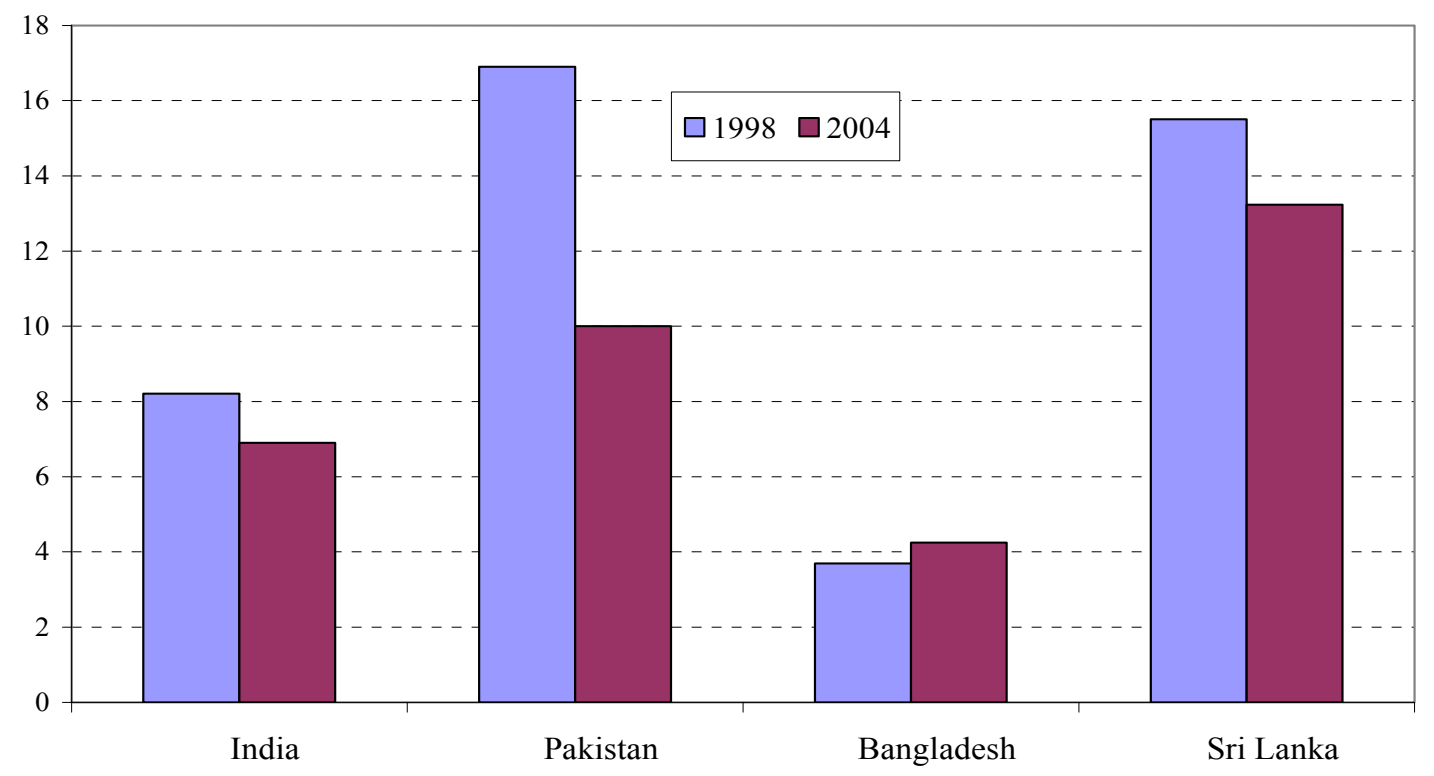

Source: National authorities.

- $\quad$ Reducing operational restrictions on staffing and branching. While restrictions are generally minimal for private banks, most staff at NCBs in South Asia continue to be governed by public sector pay scales and employment practices. Pakistan and India, as part of their efforts to modernize the public banks, have allowed for greater management discretion in human resource practices, including the ability to retrench excess staff, close unprofitable branches, and offer pay packages commensurate with those in private banks. In Sri Lanka, the two state-owned banks have been able to partially overcome strict government rules by hiring qualified staff on a contract basis.

- Lowering the cost of doing business. All four countries have pursued reforms to create a business climate more conducive to entrepreneurship and investment. This has entailed tackling corruption, reducing red tape, securing property rights, and improving the tax regime. Statutory tax rates in the banking sector remain high, however. In Bangladesh, the top corporate tax rate is 50 percent. In Pakistan, banks are taxed at a rate of 47 percent, as opposed to a top corporate tax rate of 43 percent for private firms and 35 percent for public firms. However, to boost private banking, the Pakistani government has committed to a timetable to bring down the top corporate tax rate to 35 percent by 2007 .

- Improving government debt management. Every country has taken steps to make government borrowing from the banking system more market based, including having regular auctions for government securities, and fostering the development of primary and secondary debt markets. Additionally, Pakistan and Bangladesh have 
substantially reduced the interest rates on national savings certificates, which has allowed banks to compete for funds on more favorable terms while offering longdated term deposits. This has spurred deposit growth and reduced maturity mismatches in bank balance sheets.

- Removing restrictions on international financial transactions. While all four countries have largely removed restrictions on current account transactions, capital account restrictions continue to be more tightly regulated. This stems from concerns that reducing restrictions could fuel capital outflows and facilitate money laundering. More recently, as external reserves in several of the countries have risen to more comfortable levels, capital account restrictions have been selectively eased. For example, India amended its External Commercial Borrowing guidelines in early 2004 to facilitate external corporate investment in infrastructure. In Pakistan, significant easing of capital account restrictions and the formation of exchange companies have accelerated capital account movements. The investment regime, particularly for FDI, has also been dramatically liberalized in South Asia. Bangladesh, for instance, now allows FDI in the RMG sector, both inside and outside its EPZs.

\section{Prudential control and supervision}

95. The liberalization of banking in South Asia has necessitated a vigorous focus on improving supervision and enforcement. This has entailed stepping up on-site and off-site supervision, enforcing stricter accounting and auditing standards, and imposing tighter rules on loan provisioning. In Bangladesh, an early warning system for problem banks has been introduced. Additionally, risk management and prudential guidelines for consumer credit and small business lending have been enacted. In Sri Lanka, the central bank now prepares a Financial Stability Report every six months and requires that all banks receive a credit rating. In India, the Board for Financial Supervision (BFS) meets once a month to provide guidance on regulatory policies and supervisory practices, which has resulted in numerous reforms that have helped bring banking standards closer in line with international best practices.

96. Measures have also been taken by all four countries to boost capital adequacy. In Bangladesh, the minimum capital requirement on a risk-weighted basis was raised from 8 to 9 percent and the minimum capital level raised from Tk 40 crores to Tk 100 crores (\$17 million). The capital adequacy ratio in Sri Lanka was raised to 10 percent beginning January 2003. Similar measures have been adopted in the rest of the region.

\section{Corporate governance has been a problem throughout South Asia, and steps} have been taken to redress some of the more serious weaknesses. In Bangladesh, for example, the fit and proper test for CEOs of banks has been tightened and a similar test introduced for bank directors. Independent directors are also required to represent minority shareholder and depositors' interests. Furthermore, no board can have more than one member from each family and limits have been placed on tenure and the maximum number of directors. To enhance transparency, banks are required to publish annual financial statements in newspapers. 
98. Regulators in the region have also encouraged banks to list shares on the stock market to provide public signals about the banks' financial health and to enable banks to raise additional capital. In Bangladesh, a directive is being considered to require all private banks to have publicly listed shares. However, the low level of liquidity in South Asia stock markets, deficiencies in security laws and regulations, and considerable constraints to short-selling overpriced securities have hampered the ability of stock markets to generate clear signals about the health of financial institutions.

\section{Bank restructuring}

99. With regard to bank restructuring, Pakistan has pursued a comprehensive and far-reaching program. Professional management teams from the private sector have been contracted to run state-owned banks on commercial terms. This has helped give the banks much more autonomy in their day to day operations and over medium-term strategic planning, which has led to more prudent lending practices, increased capital, and improved profitability. As part of the restructuring exercise, over 11,000 staff at NCBs in Pakistan have been retrenched through voluntary separation programs, and nearly 800 loss-making branches closed. India has also accelerated its efforts to restructure state-owned banks. In early 2005, the government granted state-owned banks greater operational and managerial freedom, including the ability to set human resource policies, establish overseas branches or subsidiaries, exit unprofitable lines of business, and acquire domestic and foreign banks.

100. Bangladesh's government has awarded contracts to internationally recognized firms to strengthen NCB operations. A management support team has been appointed at Agrani Bank while management consultants have been procured for Sonali Bank, and most recently, Janata Bank. While it is still too early to gauge the impact that these teams have had on NCB performance, it is clear that this undertaking will be valuable only if a fruitful dialogue is established among bank management, the banks' board of directors, Bangladesh Bank, and the teams themselves.

101. To ring fence and resuscitate problem banks, regulators in South Asia have made heavy use of Memoranda of Understanding (MOUs). These agreements signed with troubled banks typically spell out targets for increasing capital, enhancing profitability, and reducing operating costs. For instance, Bangladesh Bank has signed MOUs with all four NCBs, which among other things, set a ceiling on the growth in each bank's lending portfolio of between 5-8 percent, restrict single party exposure to only 5 percent of paid-up capital of each bank, and set targets on cash recoveries from defaulters, with a special focus on recovery from the top 20 largest defaulters.

\section{Divestment of NCBs}

102. Pakistan has made significant strides in divesting NCBs. While the government still retains majority equity control of the country's largest bank, National Bank of Pakistan, 
the other major NCBs have been divested. ${ }^{29}$ As a result, the market share of NCBs has declined to 22 percent in 2004, the lowest share of any country in the region. In general, Pakistan's government has pursued a variety of models for divesting its NCBs. Some banks have been sold to strategic investors with majority ownership, while others have been sold with minority ownership. Others still have been divested through management buyouts, as well as initial public offerings. The growth of market share of private banks has also been strong in the other three countries, reflecting robust economic growth and ambitious policy reforms. While the assets of state-owned banks in India continue to account for about 75 percent of banking system assets (down from 90 percent in 1991), the share of assets in wholly owned government banks has declined to 10 percent, reflecting partial divestment of equity in many of the state-owned banks.

\section{NCB Share of Banking System Assets \\ (Percent)}

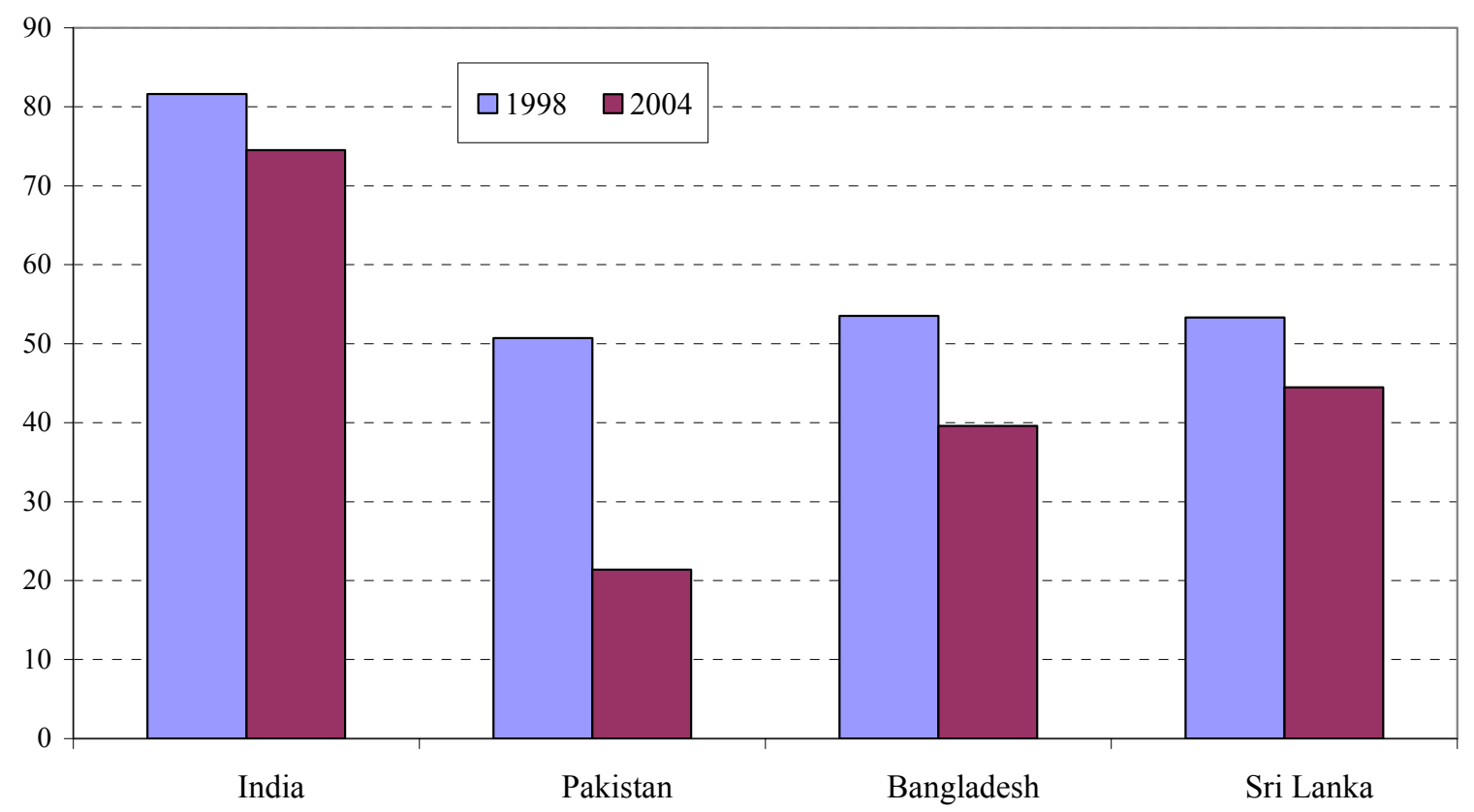

Sources: National authorities; and Fund staff estimates.

103. In general, governments in South Asia have endeavored to follow international best practices in the divestment of NCBs. This requires that: a "fit and proper" test be applied to potential bidders, the new owners be given full autonomy over human resource decisions and branch closures, the bank be recapitalized prior to divestment, and that safeguard measures be introduced, especially to prevent asset stripping in the lead up to divestment.

${ }^{29}$ To date, 23.3 percent of NBL's shares have been sold through public offerings in the stock market. 
104. Experience from other countries suggests that there are significant risks associated with divesting insolvent banks. A deeply insolvent bank has a clear incentive to take undue risks since a conservative lending and investment strategy, even if well implemented, is unlikely to generate sufficient cash flow from operations to offset the bank's expenses. This could induce the bank to increase deposit rates to attract liquidity. Thus, the government runs the risk that the insolvent bank, once divested, will grow in size and potentially become even more insolvent, thereby destabilizing the banking system and possibly forcing the government to shoulder the burden of a depositor bailout. Recapitalizing the bank prior to divestment helps to reduce this risk. Moreover, as long as the divestment process is transparent and open to many qualified bidders, it will likely be the case that the funds spent to recapitalize the bank will be largely offset by a higher sales price. In South Asia, governments have prudently avoided divesting insolvent banks. As a result, while the process of resuscitating former NCBs to health has often been a long one, no divested stateowned bank has gone on to fail.

105. An important issue is whether to move bad loans off the balance sheets of banks that are slated for divestment. The main advantage of cleansing banks of nonperforming assets is that the resulting bank will be, for the most part, a "clean bank." This will greatly facilitate the due diligence of prospective buyers as it is much easier to assess the value of an entity whose assets are well defined and generating a predictable stream of income. The chief drawback of moving the nonperforming loans (NPLs) from the books of the NCBs is that it is not clear where they should go. The value added in banking stems in part from the ability of lenders to develop relationships with borrowers that reveal the ability and inclination of the borrower to repay a loan. In this regard, valuable information may be lost if the loans are transferred to an outside agency.

106. While there is little debate about the need to recapitalize banks prior to divestment, there is no accepted standard about the degree to which the bank's operations ought to be restructured prior to sale. Pakistan has generally subjected its NCBs to a rigorous cost restructuring prior to divestment in order to bring their cost/income ratios in line with private banks. However, such a strategy was greatly facilitated by the ability of the State Bank of Pakistan to directly supervise and coordinate the restructuring efforts. In countries like Bangladesh where the central bank's authority over the NCBs is not clearly defined, it may be more appropriate to allow the strategic investor to undertake the bulk of the restructuring efforts. While this will lead to a lower price for the bank, it will likely expedite the restructuring process, since a strategic investor will be able to install new management and undertake reforms, especially those pertaining to human resource management that would be difficult to achieve while the bank is under state control.

\section{Conclusion}

107. The reform efforts undertaken by governments in South Asia have already yielded tangible results. In all four countries, NPLs have decreased significantly and capital adequacy improved (Figures 1 and 2). In Bangladesh, for instance, gross NPLs in the banking system declined from 36 percent to 22 percent of total loans and advances during 1999-2004, while the net NPL ratio declined from 33 percent to less than 16 percent. At the 
same time, the capital adequacy ratio has increased from 7 percent in 1998 to 9 percent in 2004. This has led to a healthy increase in bank share prices, with the market weight of banking stocks rising from 10 percent of total capitalization in June 1998 to 47 percent in December 2004 on the Dhaka and Chittagong stock exchanges. At the same time, the spread between deposit and lending rates has narrowed, indicating increased competition in the banking sector and better risk management.

108. Looking forward, the main challenge will be to reform and divest NCBs while strengthening private banks so that they are more resilient to external and domestic shocks. As in any industry, there will be entrenched interests that will stand to lose from increased competition in the banking system and a more vigorous effort to allocate financial resources based on commercial merit. Thus, banking reform will require a strong public consensus and resolute political will. Concerted action will be necessary to collect loans from major defaulters, improve labor policy, and wean SOEs from their reliance on easy credit from the NCBs. In Bangladesh, the central bank should be given more regulatory power over the banking system and greater jurisdiction over the pace and scope of the reform agenda.

109. Bangladesh has adopted an ambitious program for divestment of its NCBs. The government intends to divest three of the four NCBs sequentially over the next three years. The information memorandum for Rupali Bank was issued in May 2005 and the bank is expected to be sold by the end of the year. The government also intends to corporatize Agrani Bank by end-2005 and to divest it by mid-2006. In the case of Janata, the government intends to corporatize it by end-2006 and bring it to the point of divestment by mid-2007. Given Sonali's size and strong rural presence, the government has determined that the best course of action is to restructure the bank with the intent of bringing it to the point of divestment over the medium term.

110. Strengthening private banks will require a competitive market environment, continued vigilance in supervision, enhanced efforts to recover bad loans, and a stable macroeconomic climate. In order to strengthen internal controls and improve customer service, private banks in the region must move quickly to introduce information technology. Furthermore, the legislative frameworks in South Asia for loan recovery should be modernized, particularly by streamlining the legal procedures for banks to collect collateral on default loans. Bangladesh has recently moved forward in this regard by establishing specialized Money Loan Courts that provide dedicated judges and expedited procedures to resolve problem loans.

111. While there has been some consolidation in the banking systems of South Asia, many private banks continue to operate on a small scale, which has prevented them from building well diversified lending portfolios. Pakistan has sought to redress this problem by amending tax laws to facilitate merger and acquisition of banks and financial institutions by allowing group tax loss relief. In early 2005, India issued new guidelines for the merger of private sector banks to complement the guidelines already in place for nonbanking financial companies. 
112. In the years to come, banks in the region will need to develop new markets and product offerings. This will necessitate a stronger focus on lending to medium-sized enterprises and to retail clients. Additionally, there exists significant potential in expanding the markets for consumer credit, mortgage and auto finance, and insurance. Infrastructure finance has also become a priority in the region. While infrastructure investment has been traditionally financed almost exclusively through the public budget, there has recently been a push to expand the use of public-private partnerships to mobilize private financing for infrastructure and to expand the role of the private sector in infrastructure development. 
Figure 1. Net NPLs

(Percent of net loans and advances)
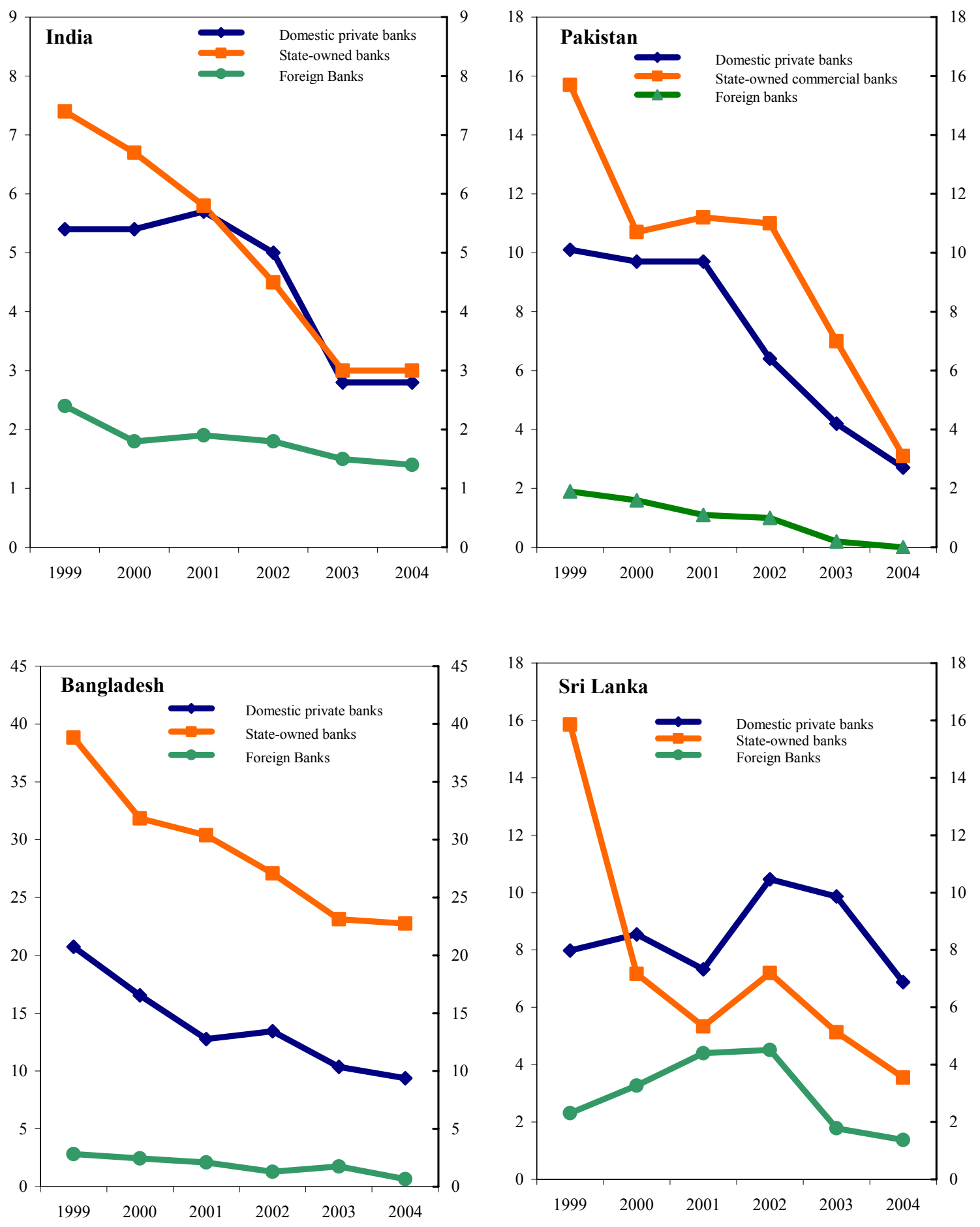

Sources: National authorities; and Fund staff estimates. 
Figure 2. Capital

\section{(Percent of risk-weighted assets)}
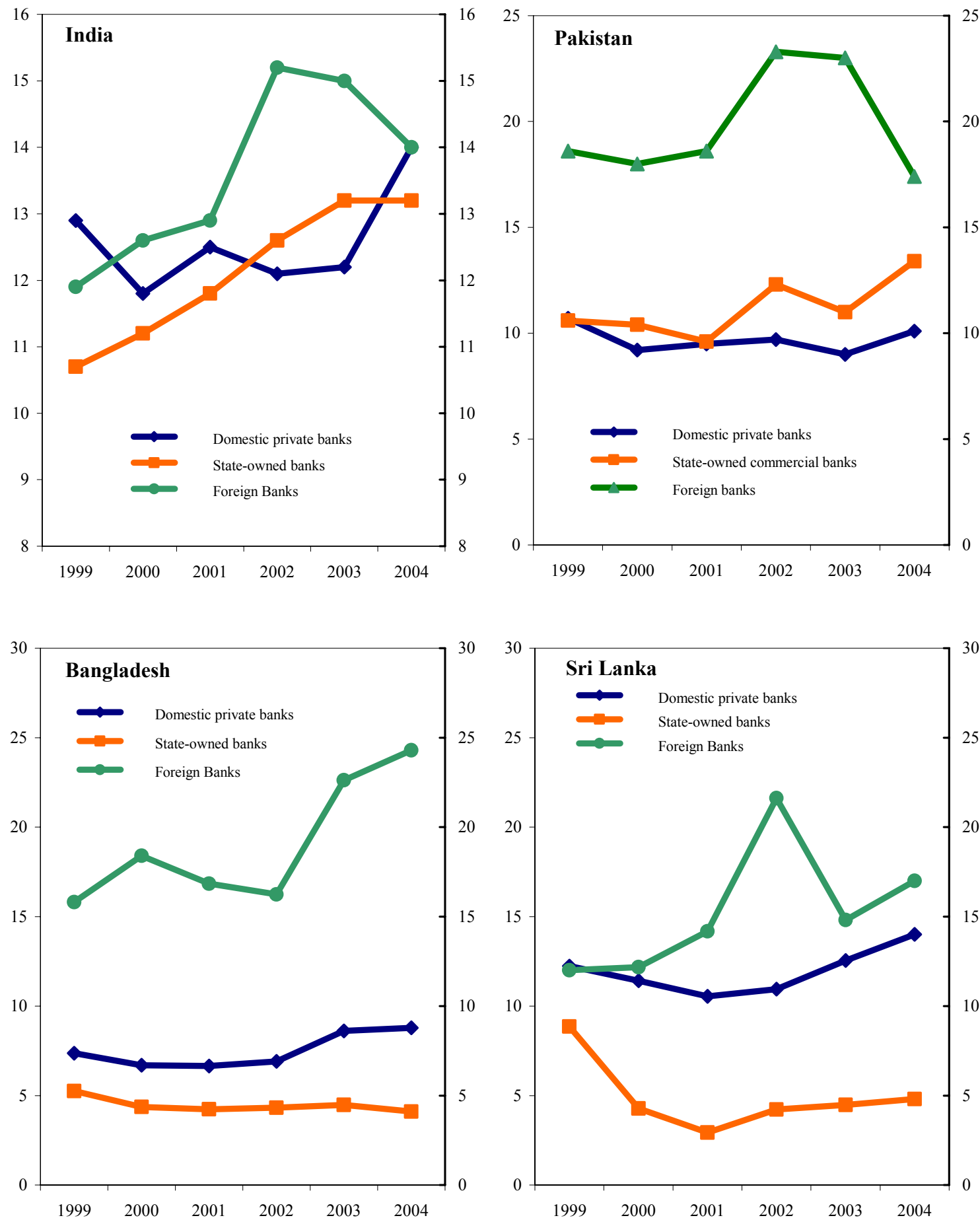

Sources: National authorities; and Fund staff estimates. 


\section{REFERENCES}

La Porta, R., F. López-de-Silanes, and A. Shleifer, 2000, “Government Ownership of Banks," Journal of Finance (February). 